\title{
Household Savings and Productive Capital Formation in Rural Vietnam: Insurance vs. Social Network
}

\author{
Thomas Gries, Ha Van Dung \\ University of Paderborn, Paderborn, Germany \\ Email: thomas.gries@notes.upb.de
}

Received 21 April 2014; revised 26 May 2014; accepted 29 June 2014

Copyright (C) 2014 by authors and Scientific Research Publishing Inc.

This work is licensed under the Creative Commons Attribution International License (CC BY). http://creativecommons.org/licenses/by/4.0/

(c) (i) Open Access

\begin{abstract}
In this paper, we investigate the role of the social network nexus and the insurance nexus in determining household savings and productive capital formation in rural Vietnam. We analyze the issue in two dimensions, stocks and flows, and consider the exposure to negative shocks. The instrumental variable method is employed and unlike previous studies, we account for the endogeneity of all concerned variables. The results indicate that the social network nexus has more impacts in "ex ante" rather than in "ex post" households. In both households groups, the effects of the insurance nexus dominate over those of the social network nexus. In the case of the stocks, we also find that the precautionary view holds in liquid assets but not in productive assets.
\end{abstract}

\section{Keywords}

Rural Households, Liquid Assets, Productive Assets, Social Networks, Organizations, Insurance, Disasters

\section{Introduction}

At the macro level, a major problem in economic development is how to increase the resources available for productive capital formation since productive capital formation and investment have a strong relationship with growth [1]-[6]. Hence, the allocation of resources between present and future consumption (savings) is one of the most fundamental economic choices in any economy.

Resources earmarked for investment and economic growth can be increased through more domestic savings. Household savings are one important part of investment [7]-[12]. In developing economies, liquid and productive capital formation not only serves economic growth but can also be used for other purposes such as the 
precautionary motive, the life cycle motive, the inter-temporal substitution motive, or the bequest motive [13]. Because the financial market in rural areas is imperfect, these motives may lead to differentiated savings behavior. Households allocate their capital in a way that fits in best with their respective motives. Unlike in developed economies, where people can put their savings into stocks and many other financial assets and where this large variety of financial assets can serve many purposes, people in developing economies have no access to this variety of assets with different purposes. These households often keep their short-term savings in the form of liquid assets such as gold, jewelry, or cash (at home and/or short-term deposits at financial institutions). Household savings with a longer-term perspective are invested in real productive assets such as land, cattle, or durables. The precautionary reason is especially important for households with no access to a formal social welfare system; indeed, most of these households are in rural areas. The main source of rural income is agriculture, which is strongly affected by adverse conditions such as diseases, pests, fires, and bad weather. Furthermore, agricultural price variability can lead to income fluctuations for the farmers. These income shocks can be effectively compensated by household savings shocks [14]. Another type of negative shock relating to household members such as illness, death, or divorce can affect household savings [15] [16].

We are motivated by two main considerations. First, most studies in the existing literature, that investigate household savings use the savings rate, defined as the ratio of monetary savings (or liquid assets) to disposable income, as the dependent variable. No study looks explicitly at asset formation or at a large variety of assets for productive capital formation. What is more, no study looks simultaneously at liquid assets and productive capital formation options in rural households in developing countries. Neither is there a study that examines both flows and stocks of savings and productive capital formation. Looking at the issue from a time dimension perspective, flows are defined as short-run (within one year) changes of the total balances of liquid and productive capital while stocks are defined as capital that has been accumulated over the long-run period. Studies that investigate long-run asset accumulation are more relevant since they can provide a general picture of household behavior during the whole lifetime of respective households. However, the investigation of household behavior in flows can be a subordinate for stocks as the results in flows can provide a picture of the considered household's behavior during one period.

Second, when examining household savings, researchers focus on two main categories of savings determinants: household characteristics and household head's characteristics [15] [17]-[28]. However, the literature pays little attention to institutional conditions, the natural and social environment, and government assistance.

Therefore, in this study we look at more than monetary savings. We include other ways of forming productive capital as well as the asset structure in terms of both flows and stocks. We look at monetary savings as the first pillar of asset composition, which fulfills the need to hold a highly liquid and flexible asset, and at real productive capital formation, the second pillar of asset accumulation in rural households. We investigate the important roles of the social network and the assistance nexus (strength of a household's social network and support system, membership in organizations, and assistance in the shape of visits from consultants (professional workers employed by the government)), as well as the impact of the insurance nexus (availability and affordability of insurance) on household savings and productive capital formation. Finally, we study these two aspects in connection with the effects of being exposed to negative shocks.

Vietnam is an interesting case to study since it has experienced strong economic growth since the late 1980s. Before that, Vietnam was one of the poorest countries in the world with GDP per capita (PPP, constant 2005 international USD) of US\$ 803 in 1985 and a GDP growth rate of around 4\% per year. However, the economy changed after the implementation of a series of innovation policies from 1986 onwards (known as "DoiMoi"). During the 1990s and 2000s, Vietnam's average GDP growth rate was $7.5 \%$ and $7.1 \%$, respectively, peaking at 10\% in 1995. GDP per capita (PPP, constant 2005 international USD) reached US\$ 2611 in 2008, approximately three times that of the 1985's figure [29]. Even though the process of industrialization and modernization has been strongly fostered, most of the population still lives in rural areas (in 2009 rural inhabitants accounted for around $70 \%$ of total population down from $76 \%$ in 2000) [30]. Owning to its long coastline, Vietnam is sensitive to natural disasters from the sea. The country stretches out from north to south with a coastline of over $3300 \mathrm{~km}$ and is hit by an average of 4 severe storms or typhoons every year. These natural negative shocks are amplified by shocks to household members such as disease or death. These shocks are always a major concern for the population in rural areas since negative shocks tend to absorb a part of households' liquid and productive assets. Accordingly, savings in the form of liquid assets and productive capital formation for precautionary reasons are almost an obligation in Vietnamese households. 
The literature has shown that both social networks and insurance can affect household savings [31]-[38] and that both can be used to compensate for the impacts of negative shocks. While social networks are considered a traditional channel in developing economies, its comparatively modern cousin-the insurance system—seems less developed due to scarce economic resources, constraints on the public sector and low institutional capacity [39]. This raises concerns about impacts of these two factors on household savings with respect to negative shocks. The question may be whether the modern scheme-insurance- -has a greater impact than the traditional one-social networks - on capital formation. The answer may have implications for policy makers, whose policies concern household savings and productive capital formation in rural Vietnam.

To test the role of the social network nexus and the insurance nexus, we employ the linear instrumental-variables method and account for the endogeneity of all concerned variables, an approach that has not been taken before in the field of household savings.

The paper is organized as follows. Section II summarizes the relevant literature of the social network and the insurance nexus. Section III describes of the data. Section IV provides the statistical methods used in the analysis. Section V discusses the empirical results and Section VI gives some conclusions and policy implications.

\section{Literature Review on the Social Network Nexus and the Insurance Nexus}

Household's connection to social networks can be separated into two main streams. The first stream connects households and household members with economic and/or social organizations. The research by Pailwar et al. (2010) investigates the impact of household members who participate. A membership is said to exist when one household member works for a financial institution. Their research finds that membership in financial institutions has a significantly positive effect on household savings. Where social organizations are concerned, membership in an occupational pension scheme in the UK is positively related to savings [36].

The second stream connects households and household members with the community. The links between households and the community can be a way for households to obtain better supports and/or to reach a higher level of experience. To study how social learning can affect the life cycle "precautionary savings" task, Ballinger et al. (2004) use experimental methods with subjects, who come from social science classes at the University of Houston, participating into three groups and each group represents a different generation. The former generation's members were observed by the successive generation's members. The results indicate that latter generations can improve their ability to solve the life cycle precautionary savings models. The results of Giles and Yoo (2007) provide support for the argument. They use household panel data from rural China and find that migrant networks that developed from the 1990s onwards have an effect on precautionary savings. Households can improve their ability to cope with risk as the networks expand. As the size of the village migrant networks increases, households engage less frequently in precautionary savings. While friends and relatives also form parts of social networks [40], their specific influence on household savings or productive capital formation has not been investigated.

Insurance and household savings can be used to pool negative shocks. The risk of unstable income or the occurrence of negative shocks can be mitigated by private and public insurance, and insurance can be used to complement household savings within the framework of such shocks. In a study on Taiwanese micro-data, Chou et al. (2003) find a negative relationship between health insurance and household precautionary savings. The empirical results suggest that the introduction and expansion of social health insurance significantly reduce households' precautionary savings. Another study by Chou et al. (2004) confirms the role of health insurance in reducing households' precautionary savings in the context of the introduction of Taiwan's National Health Insurance program in 1995.Their findings are consistent with those of other studies on the impacts of different types of insurance such as social insurance, disability insurance, and unemployment insurance [41]. In two separate studies, Gruber and Yelowitz (1999) and Maynard and Qiu (2009) investigate the effect of Medicaid, a major social insurance scheme that provides health insurance to low-income individuals in the US, on household savings. The results suggest that Medicaid has a conclusive impact on reducing household savings. However, the study by Starr-McCLuer (1996) challenges the precautionary view in that it finds a strong and positive relationship between insurance and household wealth.

The literature has identified the positive role of social networks in motivating household savings through organizational membership or a social learning effect. It empirically confirms the complementary impacts of insurance on household savings, but not on household wealth. However, no study mentions about the effect of direct 
support from the government on household savings. To close the gap in the literature, we add government assistance in the form of consultancy services, friends and relatives as components of the social network, and examine their impact on household liquid and productive capital formation. Using stocks and flows as separate categories, we can also test for the precautionary view of savings in the form of liquid assets and productive capital.

\section{Data Description}

For our analysis we use data from a household survey of rural areas in Vietnam, namely VARHS08 (Vietnam Access to Resources Household Survey: Characteristics of the Vietnamese Rural Economy, 2008 Survey). This survey was funded by Danida and executed by the Central Institute for Economic Management (CIEM), in cooperation with the University of Copenhagen, the Institute of Policy and Strategy for Agriculture and Rural Development (IPSARD), and the Institute for Labor Science and Social Affairs (ILSSA) in twelve provinces of Vietnam in 2008. The data set "was designed to provide better and more current information about key factors influencing the livelihoods and development opportunities, as well as constraints that characterize the economic environment of households in rural Vietnam" [42]. Therefore, it was the best source of detailed information on the issue this paper seeks to examine. A sample of 3227 households, for all of which complete data is available, is used. Most households (52.3\%) are located in the Northern Midlands-a mountainous area, while less than $1 \%$ are in the Mekong River delta. The remainders are located in the north central area and central highlands.

In this paper, we distinguish between liquid assets and productive assets (capital) to describe household savings and productive capital formation, so we can cover the two main categories of asset accumulation and asset holdings. Liquid assets are deposits in financial institutions, ROSCAs, private moneylenders, or cash/gold/jewelry kept at home. Such assets can be used for the short-term precautionary motive, among others. The shortterm precautionary motive also reflects the discontinuity of the income and expenditure stream. Revenues from agricultural production are random and agricultural expenditure is seasonal in nature. Therefore, liquid asset holdings can be expected to buffer this mismatch between revenue and expenditure and to smooth the income and consumption path. By contrast, productive assets are assets such as productive durable goods, cattle, and land that can yield additional income for households. As such, they form part of a wealth growth strategy. They may also serve to ensure the continued income and wealth of a household in case it sustains a larger shock. Liquid and productive assets add up to total assets (total capital formation). Each household's asset variables, stocks, and flows are related to its disposable income. A stock is a household's asset holdings at the time of interview. We determine asset ratios for the stocks of 1) liquid assets, 2) productive assets and 3) total assets. A flow is a change in asset holding (asset formation) during the previous twelve months. Hence, for the flow variables we obtain 1) a flow liquid asset ratio, which represents a liquid savings ratio, 2) a flow productive asset ratio, and 3) a total (or an overall) flow ratio. All ratios are calculated by dividing their values by the household's disposable income over the previous 12 months. For example, the flow liquid asset ratio represents the flow of liquid assets divided by the household's disposable income (measured in the previous 12 months).

Due to the large number of households (58\%) that experienced at least one negative shock during the previous year, and due to the expected effects of such a negative shock on observable asset values, we distinguish between households that sustained such a major negative shock and those that did not. For the group of households that did, we observe an "ex post" (of shock) situation with respect to precautionary asset holdings. For the group that did not experience a negative shock, we observe the "ex ante" (of shock) situation that should allow us to identify precautionary asset motives more clearly, in particular when comparing households' behavior to that of the "ex post" group. By dividing the households into these different groups we can identify "ex ante" of shock and "ex post" of shock decisions before comparing the influence of the social network nexus and the insurance nexus in household savings and productive capital formation. The variable definitions are described in the Appendix.

Table 1 provides an overview of the major characteristics of the data, broken down into three household groups: all households, "ex ante" households and "ex post" households. First, among 58\% of rural households suffered at least one negative shock during the previous 12 months, 54\% faced one economic or natural disaster, and $9 \%$ were confronted with negative shocks that originated with the household's members. These surprisingly large numbers show that disasters are an important part of life in rural Vietnam. Second, the total flow ratio in rural Vietnam is $21 \%$ and hence relatively low compared to other countries like China [17] [19]. Only one third 
Table 1. Summaries of selected variables.

\begin{tabular}{|c|c|c|c|c|c|c|}
\hline & \multicolumn{2}{|c|}{ All households } & \multicolumn{2}{|c|}{ "ex ante" households } & \multicolumn{2}{|c|}{ “ex post” households } \\
\hline & Mean & S.D. & Mean & S.D. & Mean & S.D. \\
\hline \multicolumn{7}{|l|}{ Variables } \\
\hline Total flow ratio & 0.21 & 0.77 & 0.26 & 0.73 & $0.18^{* * *}$ & 0.80 \\
\hline Flow liquid asset ratio & 0.07 & 0.13 & 0.09 & 0.15 & $0.05^{* * *}$ & 0.12 \\
\hline Flow productive asset ratio & 0.14 & 0.76 & 0.17 & 0.71 & $0.12^{*}$ & 0.79 \\
\hline Total stock ratio & 14.91 & 37.93 & 12.24 & 17.90 & $16.82^{* * *}$ & 47.30 \\
\hline Stock liquid asset ratio & 0.15 & 0.35 & 0.19 & 0.43 & $0.12^{* * *}$ & 0.27 \\
\hline Stock productive asset ratio & 14.76 & 37.94 & 12.05 & 17.92 & $16.71^{* * *}$ & 47.30 \\
\hline Shock & 0.58 & 0.49 & & & & \\
\hline Household member shocks & 0.09 & 0.28 & & & & \\
\hline Economic/natural shocks & 0.54 & 0.50 & & & & \\
\hline \multicolumn{7}{|l|}{ Household head characteristics } \\
\hline Gender & 0.82 & 0.38 & 0.80 & 0.40 & 0.84 & 0.37 \\
\hline Edu2 & 0.07 & 0.25 & 0.09 & 0.028 & 0.06 & 0.23 \\
\hline Edu3 & 0.01 & 0.12 & 0.02 & 0.14 & 0.01 & 0.09 \\
\hline \multicolumn{7}{|l|}{ Household characteristics } \\
\hline Person & 4.85 & 2.00 & 4.53 & 1.90 & 5.08 & 2.03 \\
\hline Young rate & 0.25 & 0.22 & 0.23 & 0.22 & 0.26 & 0.22 \\
\hline Old rate & 0.18 & 0.24 & 0.14 & 0.28 & 0.10 & 0.21 \\
\hline \multicolumn{7}{|l|}{ Social network } \\
\hline Supporters & 1.61 & 0.98 & 1.60 & 0.99 & 1.62 & 0.97 \\
\hline Organization & 0.79 & 0.41 & 0.76 & 0.43 & 0.81 & 0.39 \\
\hline Assistance & 4.24 & 5.71 & 4.13 & 5.80 & 4.31 & 5.65 \\
\hline Insurance & 0.82 & 0.38 & 0.78 & 0.41 & 0.86 & 0.35 \\
\hline \multicolumn{7}{|l|}{ Instruments } \\
\hline Ethnicity & 0.62 & 0.49 & 0.71 & 0.46 & 0.55 & 0.50 \\
\hline Area1 & 0.52 & 0.50 & 0.43 & 0.49 & 0.59 & 0.49 \\
\hline Area2 & 0.15 & 0.36 & 0.16 & 0.37 & 0.14 & 0.35 \\
\hline Area3 & 0.24 & 0.43 & 0.29 & 0.45 & 0.20 & 0.40 \\
\hline Observations & \multicolumn{2}{|c|}{3227} & \multicolumn{2}{|c|}{1352} & \multicolumn{2}{|c|}{1875} \\
\hline
\end{tabular}

$\left({ }^{*}\right)\left({ }^{* * *}\right)$ indicate that mean differences between "ex ante" and "ex post" households are statistical at the $10 \%$ and $1 \%$ levels of significance, respectively.

of the total flow represents flow liquid assets, a proportion that is closer to that of some transition economies [18]. The means of three flow ratios are statistically different between "ex ante" and "ex post" households. Households facing shocks have a lower rate of liquid assets and productive capital formation compared to non-shock households.

For stocks, the average ratio of total assets to net income is around 15 (times), indicating relatively high asset 
accumulation in rural households. Most assets are the productive stock of real household assets. Rural households maintain only a small share of liquid assets (cash and/or jewelry), preferring instead to invest a large proportion in profitable or productive assets such as productive durables, land, and cattle, and do not require more flexible and liquid monetary assets. In stocks, the mean differences between two household groups are statistically significant as well. However, the means of productive assets and total assets in the "ex post" group are higher than those in the "ex ante" group while the mean of liquid assets in the "ex post" group is higher. This may indicate a negative impact of shocks on household income in rural areas.

Third, most households (82.4\%) are headed by a male. This figure is comparable to data from the Philippines but higher than the figures for Zimbabwe and urban China [15] [17] [24]. The total dependency rate in these households is $36 \%$, with a young dependency rate of $25 \%$ (similar to that in urban China, but twelve per cent lower than in rural China) and an old dependency rate of $11 \%$ (similar to rural and urban China) [19].

Fourth, we consider three components of the social network. The average number of supporters who can help these households in times of difficulty is over one. This variable reflects the existence of close relationships among relatives or friends or community members and in turn suggests a functioning social network in rural areas. It also indicates an agricultural culture in which households can quite easily call on relatives, friends, and members of their community for assistance. Another social network variable is membership of organizations in rural areas. More than $70 \%$ of households have at least one household member who is affiliated with the political or a social organization such as the Political party, the Youth union, the Women's union, or with an economic organization such as a business association, a credit/microfinance association, a cooperative and so forth. Concerning assistance from local authorities and the government, rural households in these areas receive on average four non-demanded visits from agricultural consultants (professional workers) each year. These visits, a type of government assistance, serve to provide rural households with information and/or assistance on farming and livestock raising techniques, and are paid for by the government. There is no major difference between the means of "ex ante" and "ex post" households in the assistance and supporter variable.

Fifth, $82 \%$ of households have at least one type of insurance. The share of households engaging into the insurance system within the "ex post" group is higher than that of the "ex ante" group (86\% compared to 78\%).

\section{Econometric Framework}

Because of the plain cross-section data structure, the econometric model used to identify the impacts of the social network nexus and the insurance nexus is the linear instrumental-variables (IV) model. In the OLS estimation, the endogeneity may arise when the error term is systematically related to the regressors, and thus the OLS estimators are inconsistent or cannot be used for a causal interpretation. The IV model, which controls for endogeneity is employed with the two-stage least-squares (2SLS) method, which can yield the most efficient estimators [43]. The IV model takes the following form:

$$
Y_{i}=\beta_{0}+\sum_{j=1}^{J} \beta_{j} X_{j i}+\sum_{k=1}^{K} \beta_{k+J} W_{k i}+u_{i}
$$

$Y_{i}$ represents the dependent variables including the flow liquid asset ratio, the flow productive asset ratio, the total flow ratio, the stock liquid asset ratio, the stock productive asset ratio, and the total asset ratio. $J, K$ is the number of endogenous and exogenous variables, respectively. $W_{k i}$ denotes the included exogenous variables, which are uncorrelated with $u_{i}$. The five exogenously determined regressors are number of non-demanded visits measuring for the government assistance, education of household head, gender of household head, number of household members, a proxy for household size, the young rate, and the old rate of households. The number of non-demanded visits is one of our concerned variables, but it is outside the households' control so we regard it as an exogenous factor. While gender of household head is obviously exogenous, we regard the rest as exogenous variables [17] [22] [38] [44]. $X_{j i}$ denotes the endogenous regressors, which potentially correlate with $u_{i}$. They include household wealth, measured in its natural logarithm, number of supporters, membership in social/ economic organizations, and insurance. While the three latter variables are of interest to us, household wealth is one likely endogenous variable and is considered an endogenous control variable. We believe that some unobserved factors may contribute to the above endogenous variables, thus causing endogeneity in the model. A number of instruments are considered to account for the endogeneity of the potentially endogenous variables. The instruments (the excluded exogenous variables) comprise the distance between households and all-weather 
roads, ethnicity of households, age of household head, and location of households (Area1, Area2, and Area3). These instruments can fully or partly affect the endogenous regressors. As wealth is considered, the justification could be based on most instruments. While age of household head has a strong relationship with household wealth [45]-[48], distance to all-weather roads and household location can be used to measure the invisible value of houses and lots. Real estate close to all-weather or major road, which implies a convenient-transport connection, often has a higher value than properties in remote areas or those that are close a minor road. The higher value of real estate near all-weather roads can be due to the fact that these properties can be suitable as offices for small business or business rentals. The price of land varies according to geographical location. For example, one hectare of agricultural land in the Central Highland, a region that is fertile and suitable for growing highvalue crops such as rubber, cashews, or peppers, is much more expensive than comparable lots in the Northern mountainous area (unfertile one-season rice fields). The breakdown into geographical location and ethnicity can reflect a difference in culture and thus influence the number of supporters and organizational membership. For example, people in the south are said to be more open than those in central areas, so it may be relatively easier for people in the south to make friends. Another example is ethnicity. Members of the Kinh community may have easier access to organizations as this group accounted for $85.7 \%$ of the total population in 2009. The second largest ethnic group—-the Tay community—accounted for only 1.89\% [49]. The ethnic origin of households is still relatively important in Vietnam, meaning that members of larger Kinh community may have better connections and can fall back on stronger networks. Concerning the insurance variable, membership of an insurance scheme can be determined by a number of factors, including ethnicity and age of household head [50].

\section{Empirical Results}

\subsection{The Roles of the Social Network Nexus and the Insurance Nexus in Stocks}

Table 2 reports the results of stocks of liquid assets and productive assets including the diagnostic tests. The first row presents the three household groups, namely all households, "ex ante" households, and "ex post" households. For each household group, three estimations are presented with three different dependent variables each: total flow ratio, flow liquid asset ratio, and flow productive asset ratio. The estimation results are from the IV regressions since the Wooldridge's robust score test and the robust regression $\mathrm{F}$ test indicate the presence of endogeneity. The Sargan chi2 is a diagnostic test value for overindentifying restrictions.

Five estimations, i.e., (1), (3), (4), (5), and (6) with the superscript "a" use the full set of instruments while the others drop the ethnic variable from the set due to overidentifying restrictions. The ethnic variable is dropped from the estimations (2), (7), (8), and (9) because the diagnostic test of overidentifying restrictions for exogenous instruments is not satisfied when the ethnic variable is included as an instrument.

First, we examine controlled independent variables. Gender of household head seems to have less impact in both "ex ante" and "ex post" households ${ }^{1}$. There is a slight and weakly significant difference in stock productive assets in "ex ante" households and stock liquid assets in "ex post" households. This may indicate that gender difference of household's head is no longer an important factor in deciding household savings behavior in rural Vietnam. The education variable has significant impacts on a household's accumulation of savings and productive capital in rural Vietnam. Higher educational attainment on the part of a household's head indicates larger differences in both liquid and productive asset accumulation. However, the effect of education variable indicates a difference in direction between liquid and productive assets. In both household groups, households with a head educated to tertiary level tend towards a higher liquid asset rate ${ }^{2}$ while household heads educated at higher educational level indicates a lower productive asset ratio, which also determines the sign and significance level of the total stock ratio. A higher ratio of liquid assets can be explained by the fact that more highly educated level of household heads may have higher income ${ }^{3}$ and thus more resources for liquid accumulation. The results for productive assets are robust across groups and education levels. Net income may be the main reason behind the negative signs of the productive asset ratio. In line with the higher rate of liquid assets, the transformation of income to productive assets in households whose heads have higher education may be relatively lower than in base households. A greater proportion of net income may be used for other purposes such as consumption or liquid assets rather than for reinvestment in productive capital.

\footnotetext{
${ }^{1}$ In line with [15] [18] [26], but in contrast to [17] [22] [28].

${ }^{2}$ In line with [17] [23] [25], but in contrast to [18] [22].

${ }^{3}$ Both groups with higher education have a net income that is almost double the net income of the reference group (no formal qualifications).
} 
Table 2. Regression results for stocks.

\begin{tabular}{|c|c|c|c|c|c|c|c|c|c|}
\hline \multirow{3}{*}{ Variables } & \multicolumn{3}{|c|}{ All households } & \multicolumn{3}{|c|}{ "ex ante" households } & \multicolumn{3}{|c|}{ “ex post” households } \\
\hline & $(1)^{\mathrm{a}}$ & $(2)$ & $(3)^{\mathrm{a}}$ & $(4)^{\mathrm{a}}$ & $(5)^{\mathrm{a}}$ & $(6)^{\mathrm{a}}$ & (7) & (8) & (9) \\
\hline & $\begin{array}{l}\text { Total stock } \\
\text { ratio }\end{array}$ & $\begin{array}{c}\text { Stock } \\
\text { liquid } \\
\text { asset ratio }\end{array}$ & $\begin{array}{c}\text { Stock } \\
\text { productive } \\
\text { asset ratio }\end{array}$ & $\begin{array}{c}\text { Total } \\
\text { stock ratio }\end{array}$ & $\begin{array}{c}\text { Stock } \\
\text { liquid } \\
\text { asset ratio }\end{array}$ & $\begin{array}{c}\text { Stock } \\
\text { productive } \\
\text { asset ratio }\end{array}$ & $\begin{array}{l}\text { Total stock } \\
\text { ratio }\end{array}$ & $\begin{array}{c}\text { Stock } \\
\text { liquid } \\
\text { asset ratio }\end{array}$ & $\begin{array}{c}\text { Stock } \\
\text { productive } \\
\text { asset ratio }\end{array}$ \\
\hline Constant & $\begin{array}{c}-221.2^{* * *} \\
(67.59)\end{array}$ & $\begin{array}{l}1.46^{*} \\
(0.84)\end{array}$ & $\begin{array}{c}-222.5^{* * *} \\
(67.90)\end{array}$ & $\begin{array}{c}-218.4^{* * * *} \\
(80.11)\end{array}$ & $\begin{array}{c}0.54 \\
(1.161)\end{array}$ & $\begin{array}{c}-218.9^{* * * *} \\
(80.62)\end{array}$ & $\begin{array}{l}-273.3 \\
(183.2)\end{array}$ & $\begin{array}{c}3.16 \\
(1.97)\end{array}$ & $\begin{array}{l}-276.4 \\
(184.4)\end{array}$ \\
\hline \multicolumn{10}{|c|}{ Household head's characteristics } \\
\hline Gender & $\begin{array}{l}-3.21 \\
(2.21)\end{array}$ & $\begin{array}{l}0.05^{*} \\
(0.03)\end{array}$ & $\begin{array}{l}-3.25 \\
(2.23)\end{array}$ & $\begin{array}{l}-5.91^{*} \\
(3.23)\end{array}$ & $\begin{array}{l}0.007 \\
(0.04)\end{array}$ & $\begin{array}{l}-5.92^{*} \\
(3.25)\end{array}$ & $\begin{array}{l}-2.42 \\
(3.90)\end{array}$ & $\begin{array}{c}0.08^{*} \\
(0.05)\end{array}$ & $\begin{array}{l}-2.51 \\
(3.93)\end{array}$ \\
\hline Edu2 & $\begin{array}{c}-9.99^{* * *} \\
(2.22)\end{array}$ & $\begin{array}{l}0.07^{*} \\
(0.04)\end{array}$ & $\begin{array}{c}-10.06^{* * *} \\
(2.24)\end{array}$ & $\begin{array}{c}-10.28^{* * *} \\
(3.65)\end{array}$ & $\begin{array}{c}0.03 \\
(0.06)\end{array}$ & $\begin{array}{c}-10.31^{* * *} \\
(3.68)\end{array}$ & $\begin{array}{l}-7.65^{* *} \\
(3.79)\end{array}$ & $\begin{array}{c}0.06 \\
(0.05)\end{array}$ & $\begin{array}{c}-7.71^{* *} \\
(3.84)\end{array}$ \\
\hline Edu3 & $\begin{array}{c}-22.21^{* * *} \\
(4.36)\end{array}$ & $\begin{array}{l}0.35^{* * *} \\
(0.11)\end{array}$ & $\begin{array}{c}-22.53^{* * *} \\
(4.40)\end{array}$ & $\begin{array}{c}-21.42^{* * *} \\
(7.31)\end{array}$ & $\begin{array}{l}0.40^{* *} \\
(0.16)\end{array}$ & $\begin{array}{c}-21.82^{* * * *} \\
(7.38)\end{array}$ & $\begin{array}{c}-27.49^{* *} \\
(11.28)\end{array}$ & $\begin{array}{c}0.26^{*} \\
(0.15)\end{array}$ & $\begin{array}{c}-27.75^{* *} \\
(11.37)\end{array}$ \\
\hline
\end{tabular}

Household's characteristics

\begin{tabular}{|c|c|c|c|c|c|c|c|c|c|}
\hline LnWealth & $\begin{array}{c}17.41^{* * *} \\
(5.18)\end{array}$ & $\begin{array}{l}-0.09 \\
(0.06)\end{array}$ & $\begin{array}{c}17.49^{* * *} \\
(5.21)\end{array}$ & $\begin{array}{c}18.01^{* * *} \\
(6.13)\end{array}$ & $\begin{array}{l}-0.02 \\
(0.09)\end{array}$ & $\begin{array}{c}18.03^{* * *} \\
(6.17)\end{array}$ & $\begin{array}{c}20.71 \\
(13.76)\end{array}$ & $\begin{array}{l}-0.22 \\
(0.15)\end{array}$ & $\begin{array}{c}20.92 \\
(13.84)\end{array}$ \\
\hline Person & $\begin{array}{l}-4.19^{* * *} \\
(0.83)\end{array}$ & $\begin{array}{c}0.02 \\
(0.01)\end{array}$ & $\begin{array}{c}-4.19^{* * *} \\
(0.83)\end{array}$ & $\begin{array}{c}-4.28^{* * *} \\
(1.35)\end{array}$ & $\begin{array}{l}0.001 \\
(0.02)\end{array}$ & $\begin{array}{c}-4.28^{* * *} \\
(1.36)\end{array}$ & $\begin{array}{c}-5.16^{* * *} \\
(1.84)\end{array}$ & $\begin{array}{c}0.03 \\
(0.02)\end{array}$ & $\begin{array}{c}-5.19^{* * *} \\
(1.85)\end{array}$ \\
\hline Young rate & $\begin{array}{c}17.25^{* * *} \\
(5.23)\end{array}$ & $\begin{array}{l}-0.01 \\
(0.07)\end{array}$ & $\begin{array}{c}17.30^{* * *} \\
(5.31)\end{array}$ & $\begin{array}{l}11.52^{* *} \\
(5.85)\end{array}$ & $\begin{array}{c}0.05 \\
(0.12)\end{array}$ & $\begin{array}{l}11.47^{*} \\
(5.91)\end{array}$ & $\begin{array}{c}13.05 \\
(11.67)\end{array}$ & $\begin{array}{l}-0.10 \\
(0.12)\end{array}$ & $\begin{array}{c}13.15 \\
(11.74)\end{array}$ \\
\hline Old rate & $\begin{array}{c}16.29^{* * *} \\
(3.23)\end{array}$ & $\begin{array}{l}-0.08^{*} \\
(0.05)\end{array}$ & $\begin{array}{c}16.36^{* * *} \\
(3.25)\end{array}$ & $\begin{array}{c}18.08^{* * *} \\
(4.05)\end{array}$ & $\begin{array}{l}-0.08 \\
(0.06)\end{array}$ & $\begin{array}{c}18.16^{* * *} \\
(4.07)\end{array}$ & $\begin{array}{l}13.72^{*} \\
(7.11)\end{array}$ & $\begin{array}{l}-0.10 \\
(0.09)\end{array}$ & $\begin{array}{l}13.82^{*} \\
(7.17)\end{array}$ \\
\hline Supporter & $\begin{array}{c}-7.77^{* * *} \\
(1.55)\end{array}$ & $\begin{array}{l}0.15^{* * *} \\
(0.03)\end{array}$ & $\begin{array}{c}-7.88^{* * *} \\
(1.56)\end{array}$ & $\begin{array}{c}-11.98^{* * *} \\
(3.99)\end{array}$ & $\begin{array}{l}0.18^{* * *} \\
(0.06)\end{array}$ & $\begin{array}{c}-12.15^{* * *} \\
(4.01)\end{array}$ & $\begin{array}{l}-6.12 \\
(3.73)\end{array}$ & $\begin{array}{l}0.09^{* *} \\
(0.04)\end{array}$ & $\begin{array}{l}-6.21^{*} \\
(3.75)\end{array}$ \\
\hline Organization & $\begin{array}{c}9.37 \\
(8.51)\end{array}$ & $\begin{array}{l}-0.14 \\
(0.12)\end{array}$ & $\begin{array}{c}9.50 \\
(8.55)\end{array}$ & $\begin{array}{c}23.03 \\
(14.25)\end{array}$ & $\begin{array}{l}-0.12 \\
(0.21)\end{array}$ & $\begin{array}{c}23.15 \\
(14.34)\end{array}$ & $\begin{array}{l}-10.26 \\
(15.72)\end{array}$ & $\begin{array}{l}-0.07 \\
(0.15)\end{array}$ & $\begin{array}{l}-10.19 \\
(15.80)\end{array}$ \\
\hline Assistance & $\begin{array}{l}0.28^{* * *} \\
(0.10)\end{array}$ & $\begin{array}{l}-0.003 \\
(0.002)\end{array}$ & $\begin{array}{l}0.28^{* * *} \\
(0.10)\end{array}$ & $\begin{array}{l}0.45^{* *} \\
(0.20)\end{array}$ & $\begin{array}{l}-0.002 \\
(0.003)\end{array}$ & $\begin{array}{l}0.46^{* *} \\
(0.20)\end{array}$ & $\begin{array}{c}0.31 \\
(0.21)\end{array}$ & $\begin{array}{c}-0.0009 \\
(0.002)\end{array}$ & $\begin{array}{c}0.32 \\
(0.21)\end{array}$ \\
\hline Insurance & $\begin{array}{c}52.90^{* * * *} \\
(8.53)\end{array}$ & $\begin{array}{c}-0.61^{* * *} \\
(0.15)\end{array}$ & $\begin{array}{c}53.31^{* * *} \\
(8.57)\end{array}$ & $\begin{array}{l}38.47^{* * *} \\
(11.89)\end{array}$ & $\begin{array}{l}-0.38^{* *} \\
(0.17)\end{array}$ & $\begin{array}{c}38.85^{* * *} \\
(11.96)\end{array}$ & $\begin{array}{l}88.35^{* * *} \\
(26.86)\end{array}$ & $\begin{array}{c}-0.79^{* * *} \\
(0.30)\end{array}$ & $\begin{array}{l}89.14^{* * *} \\
(27.05)\end{array}$ \\
\hline \multicolumn{10}{|l|}{ Diagnostic Tests } \\
\hline $\begin{array}{l}\text { Wooldridge's robust } \\
\text { score test (p-value) }\end{array}$ & $\begin{array}{l}71.6 \\
(0.00)\end{array}$ & $\begin{array}{c}43.4 \\
(0.00)\end{array}$ & $\begin{array}{l}72.9 \\
(0.00)\end{array}$ & $\begin{array}{c}33.2 \\
(0.00)\end{array}$ & $\begin{array}{l}16.1 \\
(0.00)\end{array}$ & $\begin{array}{c}34.1 \\
(0.00)\end{array}$ & $\begin{array}{c}31.3 \\
(0.00)\end{array}$ & $\begin{array}{c}46.0 \\
(0.00)\end{array}$ & $\begin{array}{c}31.8 \\
(0.00)\end{array}$ \\
\hline $\begin{array}{l}\text { Robust regression F } \\
\text { test (p-value) }\end{array}$ & $\begin{array}{l}17.9 \\
(0.00)\end{array}$ & $\begin{array}{c}11.1 \\
(0.00)\end{array}$ & $\begin{array}{c}18.2 \\
(0.00)\end{array}$ & $\begin{array}{c}7.8 \\
(0.00)\end{array}$ & $\begin{array}{c}4.1 \\
(0.00)\end{array}$ & $\begin{array}{c}8.1 \\
(0.00)\end{array}$ & $\begin{array}{c}7.8 \\
(0.00)\end{array}$ & $\begin{array}{l}11.8 \\
(0.00)\end{array}$ & $\begin{array}{c}7.9 \\
(0.00)\end{array}$ \\
\hline $\begin{array}{l}\text { Sargan Test chi2 } \\
\text { (p-value) }\end{array}$ & $\begin{array}{l}5.50 \\
(0.14)\end{array}$ & $\begin{array}{l}1.53 \\
(0.47)\end{array}$ & $\begin{array}{c}5.55 \\
(0.14)\end{array}$ & $\begin{array}{c}2.98 \\
(0.39)\end{array}$ & $\begin{array}{c}0.14 \\
(0.99)\end{array}$ & $\begin{array}{c}2.97 \\
(0.40)\end{array}$ & $\begin{array}{c}0.91 \\
(0.64)\end{array}$ & $\begin{array}{l}1.04 \\
(0.60)\end{array}$ & $\begin{array}{c}0.91 \\
(0.64)\end{array}$ \\
\hline Observations & 3227 & 3227 & 3227 & 1352 & 1352 & 1352 & 1875 & 1875 & 1875 \\
\hline
\end{tabular}

Robust standard errors in parentheses, ${ }^{* * *} \mathrm{p}<0.01,{ }^{* *} \mathrm{p}<0.05,{ }^{*} \mathrm{p}<0.1$; ${ }^{\mathrm{a}}$ Employ full set of instruments: Distance, Ethnicity, Lnage, Lnage2, Area1, Area2, and Area3. Others use the set of instruments without Ethnicity.

Number of household members has consistently negative effects on both household groups in terms of their productive asset ratios, yet there is no significant impact on liquid assets. More members may need more resources for consumption, so among them there may be greater demand for available cash. The dependency rate (young rate and old rate) seems to have a greater effect on the "ex ante" household group than on the "ex post" household group. The results indicate that a higher dependency rate may imply a lower level of net income. It is assumed that with a constant level of net income transformed into productive assets, households with a lower net 
income will have a higher rate of productive assets (and in turns, a higher total asset ratio).

Turning to the central question of the study, we investigate the impacts of the social network nexus and the insurance nexus on household savings and productive capital formation, in reference to exposure to shocks. Within the social network nexus, the role of the supporter variable seems to be more important than those of organization and assistance variables. A higher number of supporters can promote liquid assets but reduce the rate of productive assets in both "ex ante" and "ex post" households. More supporters may mean more help, so a higher number of supporters may reduce the significance of the precautionary motive and hence the value of liquid assets. However, this is not what we observe. In fact, these households have a higher ratio of liquid assets. One explanation could be that these assets reflect a smoothing of consumption and income variations, rather than being evidence of precautionary activity because of a major threat. In other words, a strong social network represented by number of supporters allows households to retain greater liquid assets in order to smooth short-term smaller fluctuations, including a kind of down-payment motive, such that households are put in a position to wait for a better price or sufficient resources before acquiring a productive asset.

While membership in an organization has no impact on capital formation, the number of non-demanded visits (assistance) can increase the productive asset and total asset ratios only in "ex ante" households. The result may indicate the effectiveness of the assistance scheme in that it enhances the household's ability to transfer its income into productive assets. However, assistance has no effect on capital accumulation in "ex post" households.

The analysis may imply that the social network nexus works in "ex ante" households rather than in "ex post" households. This means that social networks seem to have an insignificant role when it comes to making households more resilient to shocks.

The results of the insurance nexus are split into two directions. The precautionary view, which is supported in the literature, is held when we consider the liquid assets of households. The results are identical in both "ex ante" and "ex post" household groups when households with insurance accumulate a smaller portion of monetary assets compared to those without insurance. The second direction relates to the statistically significant impacts of insurance on productive assets. Our finding confirms the argument of Starr-McCluer (1996) that there is a strongly and positively significant relationship between insurance and household productive assets. The results are robust across households and the accumulation process can be used to explain the strong and positive effects of insurance. Households with insurance can increase their ability to accumulate productive assets and form stocks. This may also be in accordance with the lower rate of liquid assets.

Compared to the social network nexus, the role of the insurance nexus seems to be dominant in both "ex ante" and "ex post" household groups. Insurance may not only help households increase their productive capital formation, but also insure households against risk.

\subsection{The Roles of the Social Network Nexus and the Insurance Nexus in Flows}

A similar method is applied to analyze the flows of household liquid assets and productive assets. In Table 3, five estimations, i.e., (3), (5), (6), (7), and (9) with the superscript "a" use the full set of instruments (Distance, Ethnicity, Lnage, Lnage2, Area1, Area2, and Area3), while the other estimations excludes the ethnic variable from the set.

Concerning the social network nexus, the number of supporters seems to have an effect only on the liquid assets of "ex ante" households. The number of supporters has no impact on the "ex post" group. It seems that these households have to deal with the fallout from negative shocks themselves. Help from friends and/or relatives does not change their liquid and productive asset ratios.

Organization membership has little effect on liquid assets and no impact on productive capital. It can affect households in that it reduces the liquid asset ratio within the "ex ante" group, but this effect is not present within the "ex post" households. This means that membership does not influence household behavior in case of negative shocks.

Assistance seems to have a greater impact in the social network nexus. It affects not only liquid assets but also productive assets of "ex ante" households. A higher number of non-demanded visits may induce these households to spend more on consumption rather than liquid or productive assets. Another intuitive explanation could be that the visits from agricultural consultants help households to increase their net income and when their consumption rises, their liquid and productive capital ratios may fall. Within the social network nexus, assistance may be the most important factor affecting, both liquid and productive assets. However, the magnitude of the 
Table 3. Regression results for flows.

\begin{tabular}{|c|c|c|c|c|c|c|c|c|c|}
\hline \multirow{3}{*}{ Variables } & \multicolumn{3}{|c|}{ All households } & \multicolumn{3}{|c|}{ "ex ante" households } & \multicolumn{3}{|c|}{ “ex post” households } \\
\hline & (1) & (2) & $(3)^{\mathrm{a}}$ & (4) & $(5)^{\mathrm{a}}$ & $(6)^{\mathrm{a}}$ & $(7)^{\mathrm{a}}$ & (8) & $(9)^{\mathrm{a}}$ \\
\hline & $\begin{array}{l}\text { Total flow } \\
\text { ratio }\end{array}$ & $\begin{array}{c}\text { Flow } \\
\text { liquid } \\
\text { asset ratio }\end{array}$ & $\begin{array}{c}\text { Flow } \\
\text { productive } \\
\text { asset ratio }\end{array}$ & $\begin{array}{l}\text { Total flow } \\
\text { ratio }\end{array}$ & $\begin{array}{c}\text { Flow } \\
\text { liquid } \\
\text { asset ratio }\end{array}$ & $\begin{array}{c}\text { Flow } \\
\text { productive } \\
\text { asset ratio }\end{array}$ & $\begin{array}{l}\text { Total flow } \\
\text { ratio }\end{array}$ & $\begin{array}{c}\text { Flow } \\
\text { liquid } \\
\text { asset ratio }\end{array}$ & $\begin{array}{c}\text { Flow } \\
\text { productive } \\
\text { asset ratio }\end{array}$ \\
\hline Constant & $\begin{array}{l}4.45^{* *} \\
(1.99)\end{array}$ & $\begin{array}{l}1.68^{* * *} \\
(0.55)\end{array}$ & $\begin{array}{c}2.64 \\
(1.66)\end{array}$ & $\begin{array}{c}5.02 \\
(3.30)\end{array}$ & $\begin{array}{l}1.69^{* *} \\
(0.77)\end{array}$ & $\begin{array}{c}3.18 \\
(2.50)\end{array}$ & $\begin{array}{c}6.84 \\
(4.42)\end{array}$ & $\begin{array}{l}2.70^{* * *} \\
(1.35)\end{array}$ & $\begin{array}{c}4.59 \\
(3.87)\end{array}$ \\
\hline \multicolumn{10}{|c|}{ Household head's characteristics } \\
\hline Gender & $\begin{array}{l}0.17^{* * *} \\
(0.06)\end{array}$ & $\begin{array}{l}0.05^{* * *} \\
(0.02)\end{array}$ & $\begin{array}{l}0.12^{* *} \\
(0.05)\end{array}$ & $\begin{array}{c}0.20 \\
(0.12)\end{array}$ & $\begin{array}{c}0.05 \\
(0.03)\end{array}$ & $\begin{array}{c}0.15 \\
(0.09)\end{array}$ & $\begin{array}{l}0.15^{*} \\
(0.08)\end{array}$ & $\begin{array}{c}0.06^{*} \\
(0.03)\end{array}$ & $\begin{array}{c}0.11 \\
(0.07)\end{array}$ \\
\hline Edu2 & $\begin{array}{c}0.12 \\
(0.09)\end{array}$ & $\begin{array}{l}0.05^{* *} \\
(0.02)\end{array}$ & $\begin{array}{c}0.06 \\
(0.08)\end{array}$ & $\begin{array}{c}0.22 \\
(0.20)\end{array}$ & $\begin{array}{c}0.07^{*} \\
(0.04)\end{array}$ & $\begin{array}{c}0.16 \\
(0.17)\end{array}$ & $\begin{array}{c}0.02 \\
(0.08)\end{array}$ & $\begin{array}{c}0.03 \\
(0.04)\end{array}$ & $\begin{array}{c}-0.006 \\
(0.06)\end{array}$ \\
\hline Edu3 & $\begin{array}{l}0.48^{* * * *} \\
(0.15)\end{array}$ & $\begin{array}{l}0.19^{* * *} \\
(0.05)\end{array}$ & $\begin{array}{l}0.26^{* *} \\
(0.12)\end{array}$ & $\begin{array}{l}0.75^{* * *} \\
(0.29)\end{array}$ & $\begin{array}{l}0.23^{* * *} \\
(0.09)\end{array}$ & $\begin{array}{l}0.45^{* *} \\
(0.22)\end{array}$ & $\begin{array}{c}0.45 \\
(0.28)\end{array}$ & $\begin{array}{l}0.20^{* *} \\
(0.09)\end{array}$ & $\begin{array}{c}0.30 \\
(0.24)\end{array}$ \\
\hline
\end{tabular}

Household's characteristics

\begin{tabular}{|c|c|c|c|c|c|c|c|c|c|}
\hline LnWealth & $\begin{array}{l}-0.28^{*} \\
(0.15)\end{array}$ & $\begin{array}{c}-0.11^{* * *} \\
(0.04)\end{array}$ & $\begin{array}{l}-0.16 \\
(0.13)\end{array}$ & $\begin{array}{l}-0.33 \\
(0.25)\end{array}$ & $\begin{array}{l}-0.12^{* *} \\
(0.06)\end{array}$ & $\begin{array}{l}-0.20 \\
(0.19)\end{array}$ & $\begin{array}{l}-0.49 \\
(0.33)\end{array}$ & $\begin{array}{l}-0.19^{*} \\
(0.10)\end{array}$ & $\begin{array}{l}-0.32 \\
(0.29)\end{array}$ \\
\hline Person & $\begin{array}{l}0.06^{* *} \\
(0.03)\end{array}$ & $\begin{array}{l}0.02^{* * *} \\
(0.008)\end{array}$ & $\begin{array}{c}0.03 \\
(0.02)\end{array}$ & $\begin{array}{l}0.12^{* *} \\
(0.06)\end{array}$ & $\begin{array}{l}0.03^{* *} \\
(0.01)\end{array}$ & $\begin{array}{c}0.08^{*} \\
(0.04)\end{array}$ & $\begin{array}{c}0.05 \\
(0.04)\end{array}$ & $\begin{array}{l}0.03^{* *} \\
(0.01)\end{array}$ & $\begin{array}{c}0.03 \\
(0.04)\end{array}$ \\
\hline Young rate & $\begin{array}{l}-0.04 \\
(0.17)\end{array}$ & $\begin{array}{l}-0.04 \\
(0.04)\end{array}$ & $\begin{array}{l}-0.04 \\
(0.14)\end{array}$ & $\begin{array}{l}-0.20 \\
(0.28)\end{array}$ & $\begin{array}{l}-0.06 \\
(0.07)\end{array}$ & $\begin{array}{l}-0.23 \\
(0.21)\end{array}$ & $\begin{array}{l}-0.16 \\
(0.29)\end{array}$ & $\begin{array}{l}-0.09 \\
(0.08)\end{array}$ & $\begin{array}{l}-0.04 \\
(0.25)\end{array}$ \\
\hline Old rate & $\begin{array}{c}-0.35^{* * *} \\
(0.09)\end{array}$ & $\begin{array}{c}-0.10^{* * *} \\
(0.03)\end{array}$ & $\begin{array}{c}-0.24^{* * *} \\
(0.07)\end{array}$ & $\begin{array}{c}-0.37^{* *} \\
(0.17)\end{array}$ & $\begin{array}{l}-0.09^{* *} \\
(0.04)\end{array}$ & $\begin{array}{c}-0.25^{* *} \\
(0.12)\end{array}$ & $\begin{array}{c}-0.37^{* * *} \\
(0.14)\end{array}$ & $\begin{array}{c}-0.13^{* *} \\
(0.05)\end{array}$ & $\begin{array}{c}-0.26^{* *} \\
(0.12)\end{array}$ \\
\hline Supporter & $\begin{array}{c}0.08 \\
(0.06)\end{array}$ & $\begin{array}{l}0.07^{* * *} \\
(0.02)\end{array}$ & $\begin{array}{l}-0.04 \\
(0.03)\end{array}$ & $\begin{array}{l}0.35^{* *} \\
(0.18)\end{array}$ & $\begin{array}{l}0.12^{* * * *} \\
(0.04)\end{array}$ & $\begin{array}{c}0.10 \\
(0.11)\end{array}$ & $\begin{array}{l}-0.08 \\
(0.06)\end{array}$ & $\begin{array}{c}0.01 \\
(0.03)\end{array}$ & $\begin{array}{l}-0.07 \\
(0.04)\end{array}$ \\
\hline Organization & $\begin{array}{l}-0.26 \\
(0.23)\end{array}$ & $\begin{array}{l}-0.07 \\
(0.07)\end{array}$ & $\begin{array}{l}-0.17 \\
(0.18)\end{array}$ & $\begin{array}{l}-0.72 \\
(0.55)\end{array}$ & $\begin{array}{l}-0.24^{*} \\
(0.14)\end{array}$ & $\begin{array}{l}-0.51 \\
(0.41)\end{array}$ & $\begin{array}{l}-0.20 \\
(0.32)\end{array}$ & $\begin{array}{l}0.003 \\
(0.09)\end{array}$ & $\begin{array}{l}-0.21 \\
(0.28)\end{array}$ \\
\hline Assistance & $\begin{array}{l}-0.01^{* * *} \\
(0.004)\end{array}$ & $\begin{array}{c}-0.004^{* * *} \\
(0.001)\end{array}$ & $\begin{array}{c}-0.004^{*} \\
(0.002)\end{array}$ & $\begin{array}{l}-0.03^{* *} \\
(0.01)\end{array}$ & $\begin{array}{c}-0.005^{* *} \\
(0.002)\end{array}$ & $\begin{array}{l}-0.01^{*} \\
(0.007)\end{array}$ & $\begin{array}{c}-0.0002 \\
(0.003)\end{array}$ & $\begin{array}{c}-0.0008 \\
(0.001)\end{array}$ & $\begin{array}{r}-0.0007 \\
(0.003)\end{array}$ \\
\hline Insurance & $\begin{array}{c}-1.23^{* * *} \\
(0.36)\end{array}$ & $\begin{array}{c}-0.49^{* * *} \\
(0.10)\end{array}$ & $\begin{array}{l}-0.54^{* *} \\
(0.22)\end{array}$ & $\begin{array}{c}-1.72^{* * *} \\
(0.61)\end{array}$ & $\begin{array}{c}-0.39^{* * *} \\
(0.12)\end{array}$ & $\begin{array}{c}-0.94^{* *} \\
(0.41)\end{array}$ & $\begin{array}{l}-0.76^{*} \\
(0.42)\end{array}$ & $\begin{array}{c}-0.52^{* * *} \\
(0.20)\end{array}$ & $\begin{array}{l}-0.46 \\
(0.35)\end{array}$ \\
\hline \multicolumn{10}{|l|}{ Diagnostic Tests } \\
\hline $\begin{array}{l}\text { Wooldridge's robust } \\
\text { score test (p-value) }\end{array}$ & $\begin{array}{c}27.3 \\
(0.00)\end{array}$ & $112.7(0.00)$ & $\begin{array}{l}13.9 \\
(0.00)\end{array}$ & $\begin{array}{l}19.1 \\
(0.00)\end{array}$ & $\begin{array}{c}55.1 \\
(0.00)\end{array}$ & $\begin{array}{c}9.8 \\
(0.04)\end{array}$ & $\begin{array}{l}24.6 \\
(0.00)\end{array}$ & $\begin{array}{c}66.4 \\
(0.00)\end{array}$ & $\begin{array}{c}10.4 \\
(0.03)\end{array}$ \\
\hline $\begin{array}{l}\text { Robust regression } F \\
\text { test (p-value) }\end{array}$ & $\begin{array}{c}7.0 \\
(0.00)\end{array}$ & $\begin{array}{l}29.6 \\
(0.00)\end{array}$ & $\begin{array}{c}3.5 \\
(0.00)\end{array}$ & $\begin{array}{c}4.7 \\
(0.00)\end{array}$ & $\begin{array}{c}14.1 \\
(0.00)\end{array}$ & $\begin{array}{c}2.5 \\
(0.04)\end{array}$ & $\begin{array}{c}6.3 \\
(0.00)\end{array}$ & $\begin{array}{l}17.4 \\
(0.00)\end{array}$ & $\begin{array}{c}2.6 \\
(0.03)\end{array}$ \\
\hline $\begin{array}{l}\text { Sargan Test chi2 } \\
\text { (p-value) }\end{array}$ & $\begin{array}{c}2.94 \\
(0.23)\end{array}$ & $\begin{array}{c}2.34 \\
(0.31)\end{array}$ & $\begin{array}{c}3.83 \\
(0.28)\end{array}$ & $\begin{array}{l}1.27 \\
(0.53)\end{array}$ & $\begin{array}{c}2.20 \\
(0.53)\end{array}$ & $\begin{array}{c}3.15 \\
(0.39)\end{array}$ & $\begin{array}{c}2.11 \\
(0.55)\end{array}$ & $\begin{array}{l}1.10 \\
(0.58)\end{array}$ & $\begin{array}{l}1.29 \\
(0.73)\end{array}$ \\
\hline Observations & 3227 & 3227 & 3227 & 1352 & 1352 & 1352 & 1875 & 1875 & 1875 \\
\hline
\end{tabular}

Robust standard errors in parentheses, ${ }^{* * *} \mathrm{p}<0.01,{ }^{* *} \mathrm{p}<0.05,{ }^{*} \mathrm{p}<0.1$; ${ }^{\mathrm{a}}$ Employ full set of instruments: Distance, Ethnicity, Lnage, Lnage2, Area1, Area2, and Area3. Others use the set of instruments without Ethnicity.

insurance coefficient is relatively small.

On the other side- the insurance nexus - the results show that except for the estimation of the flow productive assets, insurance is statistically significant in other estimations. It can be said that insurance participation confirms the precautionary view as stated in the literature [33] [38] [41] [51]-[53]. "Ex ante" households that are signed up to insurance scheme have lower rates in both flow liquid assets and flow productive assets. Accordingly, they may spend more on consumption than on savings in the shape of liquid and productive assets, lead- 
ing to lower ratios in these categories. The findings also reflect the fact that some productive assets may function as precautionary assets, so it appears that insurance substitutes for the need to save and allows for more consumption. There are hardly any observable effects of insurance on households that sustain a shock. However, it seems they have more liquid assets if they are insured. The findings concerning insurance in rural Vietnam are similar to those in China after the Chinese government increased health spending for rural households [54]. In "ex post" households, the insurance variable secures the precautionary role in liquid assets only. This may indicate that shocks equally affect household productive assets regardless of insurance. One significant difference compared to stocks is the signs of the coefficients of productive assets. We expect positive effects in both cases, stocks and flows but the signs turn out to be negative in flows. One factor that can affect the different signs is the time dimension. In flows, the time period is quite short for households with insurance to accumulate enough resources to acquire a high-value productive asset and what is more, they have no strong demand for liquid assets. It may be asked "where these households put their liquid assets in order to produce a positive effect of productive assets in stocks" The answer may be that they do not employ savings mechanisms for their liquid assets, but they do take part in the informal credit market. They play the role of private creditor who lends their monetary savings, which in this case are not accounted in liquid assets, thus leading to a smaller rate of liquid assets. In stocks, the accumulation process happens over a long time and these households can regain their credits back and transform their liquid assets plus credits into productive assets, yielding the positive signs of productive assets in flows.

The above analysis indicates that in flows the insurance nexus is also dominant in household savings and productive asset formation in both "ex ante" and "ex post" groups. Within the "ex ante" group, social networks have an impact on liquid assets and minor effects on productive assets, while insurance has a relatively larger effect on household behavior in both categories. In the "ex post" group, while insurance has an impact on liquid assets, social networks make no difference.

\section{Conclusions and Policy Implications}

To sum up, the social network nexus and the insurance nexus are shown to play a significant role in household savings and productive capital formation. Using the IV estimation, we identify that in stocks or in the long-term, the role of social networks is inconclusive in "ex ante" households while we find no relationship between social networks and household savings and asset formation in "ex post" households. The insurance variable seems to have a greater impact as it affects both liquid and productive assets in both household groups. While liquid assets still follow the precautionary argument, productive assets are found to have a positive relationship with insurance. In flows or in the short-term, social networks support the precautionary view of "ex ante" households, while insurance is shown to play a role in both "ex ante" and "ex post" household groups. In conclusion, the insurance nexus is dominant compared to the social network nexus when it comes to determining household savings and productive capital formation in rural Vietnam.

The analysis also produces some policy implications. First, governmental assistance has a positive effect on household savings in the short-term in that it reduces the liquid savings while increasing productive asset accumulation in the long-term. Technical assistance may be important for farming processes and thus can raise the agricultural output of rural households. Technical assistance cannot alone create higher income for rural households. In addition to an increase in output, a price policy should be implemented to guarantee a stable income from agriculture. The price policy is important since for many years, agriculture producers have often faced a cycle involving: low prices plus high output or low output plus high prices.

Second, the role of insurance is identified and shown to be more important than the traditional method (social networks) in influencing the precautionary motive of savings. Participating in an insurance scheme can help rural households to cope with the occurrence of negative shocks. Promoting insurance participation may be one way to encourage productive asset accumulation, which can yield additional value, and produce additional assets that can then, be reinvested in the economy.

\section{References}

[1] Blomstrom, M., Lipsey, R.E. and Zejan, M. (1996) Is Fixed Investment the Key to Economic Growth? The Quarterly Journal of Economic, 111, 269-276. http://dx.doi.org/10.2307/2946665

[2] Chow, G.C. (1993) Capital Formation and Economic Growth in China. The Quarterly Journal of Economics, 108, 809- 
842. http://dx.doi.org/10.2307/2118409

[3] Coen, R.M. and Hickman, B.G. (1980) Investment and Growth in an Econometric Model of the United States. American Economic Review, 70, 214-219.

[4] Denison, E.F. (1980) The Contribution of Capital to Economic Growth. American Economic Review, 70, 157-163.

[5] Eisner, R. (1980) Total Income, Total Investment, and Growth. American Economic Review, 70, 225-231.

[6] Papanek, G.F. (1973) Aid, Foreign Private Investment, Savings, and Growth in Less Developed Countries. Journal of Political Economy, 81, 120-130. http://dx.doi.org/10.1086/260009

[7] Ang, J. (2009) Household Saving Behavior in an Extended Life-Cycle Model: A Comparative Study of China and India. Journal of Development Studies, 45, 1344-1359. http://dx.doi.org/10.1080/00220380902935840

[8] Bellone, F. (2008) The Role of Domestic Savings in Outward-Oriented Growth Strategies. Journal of Evolutionary Economics, 18, 183-199. http://dx.doi.org/10.1007/s00191-007-0083-3

[9] Brahmasrene, T. and Jiranyakul, K. (2009) Capital Mobility in Asia: Evidence from Bonds Testing of Cointegration between Savings and Investment. Journal of the Asia Pacific Economy, 14, 262-269. http://dx.doi.org/10.1080/13547860902975077

[10] Esso, L.J. and Keho, Y. (2010) The Savings-Investment Relationship: Co-Integration and Causality Evidence from Uemoa Countries. International Journal of Economics and Finance, 2, 174-181. http://dx.doi.org/10.5539/ijef.v2n1p174

[11] Herwartz, H. and Xu, F. (2009) Panel Data Model Comparison for Empirical Saving-Investment Relation. Applied Economic Letters, 16, 803-807. http://dx.doi.org/10.1080/13504850701221949

[12] Hyun, K.N., Adam, D.W. and Hushak, L.J. (1979) Rural Household Savings Behavior in South Korea, $1962-76$. American Journal of Agricultural Economics, 61, 448-454. http://dx.doi.org/10.2307/1239430

[13] Browning, M. and Lusardi, A. (1996) Household Saving: Micro Theories and Micro Facts. Journal of Economic Literature, 34, 1797-1855.

[14] Modena, F. and Gilbert, C.L. (2012) Household Responses to Economic and Demographic Shocks: Marginal Logit Analysis Using Indonesia Data. The Journal of Development Studies, 48, 1306-1322. http://dx.doi.org/10.1080/00220388.2012.685723

[15] Ersado, L., Alderman, H. and Alwang, J. (2003) Changes in Consumption and Saving Behavior before and after Economic Shocks: Evidence from Zimbabwe. Journal of Development Studies, 52, 187-215.

[16] Filippo, P. and Luigi, V. (2012) Family Dissolution and Precautionary Savings: An Empirical Analysis. Review of Economics of the Households, 10, 573-595. http://dx.doi.org/10.1007/s11150-011-9127-4

[17] Feng, J, He, L. and Sato, H. (2011) Public Pension and Household Saving: Evidence for Urban China. Journal of Comparative Economics, 39, 470-485. http://dx.doi.org/10.1016/j.jce.2011.01.002

[18] Denizer, C., Wolf, H. and Ying, Y. (2002) Household Savings in the Transition. Journal of Comparative Economics, 30, 463-473. http://dx.doi.org/10.1006/jcec.2002.1792

[19] Horioka, C.Y. and Wan, J. (2007) The Determinants of Household Saving in China: A Dynamic Panel Analysis of Provincial Data. Journal of Money, Credit and Banking, 39, 2077-2096. http://dx.doi.org/10.1111/j.1538-4616.2007.00099.x

[20] Kelley, A.C. and Williamson, J.G. (1968) Household Saving Behavior in the Developing Countries: The Indonesian Case. Economic Development \& Cultural Change, 16, 385-403. http://dx.doi.org/10.1086/450300

[21] Kraay, A. (2000) Household Saving in China. World Bank Economic Review, 14, 545-570.

[22] Kulikov, D., Paabut, A. and Staehr, K. (2007) A Microeconometric Analysis of Household Saving in Estonia: Income, Wealth and Financial Exposure. Working Paper of Eesti Pank 8, Tallinn, 1-42.

[23] Newman, C., Tarp, F., Broeck, K.V., Quang, C.T. and Khai, L.D. (2007) Household Savings in Vietnam: Insights from a 2006 Rural Household Survey. Vietnam Economic Management Review, 1, 34-40.

[24] Orbeta, J.A.C. (2006) Children and Household Savings in the Philippines. Discussion Paper Series No 2006-14 of Philippine Institute for Development Studies, Makati City, Philippines.

[25] Pailwar, V.K., Kaur, J., Saxena, K. and Nijhara, M. (2010) Impact of Membership of Financial Institutions on Rural Saving: A Micro-Level Study. International Business and Economics Research Journal, 9, 139-147.

[26] Paxton, J. (2001) Subsistence Savings Strategies of Male- and Female-Headed Households: Evidence from Mexico. Eastern Economic Journal, 35, 209-231. http://dx.doi.org/10.1057/eej.2008.12

[27] Ramanathan, R. (1968) Estimating the Permanent Income of a Household: An Application to Indian Data. Review of Economics and Statistics, 50, 383-388. http://dx.doi.org/10.2307/1937932

[28] Seguino, S. and Floro, M.S. (2003) Does Gender Have Any Effect on Aggregate Saving? An Empirical Analysis. In- 
ternational Review of Applied Economics, 17, 147-166.

[29] WB (2012) World Development Indicators and World Development Finance. World Bank, Washington DC.

[30] GSO (2010) Vietnam General Statistics Office. Hanoi.

[31] Ballinger, T.P., Palumbo, M.G. and Wilcox, N.T. (2004) Precautionary Saving and Social Learning across Generations: An Experiment. The Economic Journal, 113, 920-947.

[32] Beverly, S.G. and Sherraden, M. (1999) Institutional Determinants of Saving: Implications for Low-Income Households and Public Policy. Journal of Socio-Economics, 28, 457-473. http://dx.doi.org/10.1016/S1053-5357(99)00046-3

[33] Chou, S.Y., Liu, J.T. and Hammitt, J.K. (2003) National Health Insurance and Precautionary Saving: Evidence from Taiwan. Journal of Public Economics, 87, 1873-1894. http://dx.doi.org/10.1016/S0047-2727(01)00205-5

[34] Engelhardt, G.V. (1996) Tax Subsidies and Household Saving: Evidence from Canada. The Quarterly Journal of Economics, 111, 1237-1268. http://dx.doi.org/10.2307/2946714

[35] Giles, J. and Yoo, K. (2007) Precautionary Behavior, Migrant Network, and Household Consumption Decisions: An Empirical Analysis Using Household Panel Data from Rural China. The Review of Economics and Statistics, 89, 534-551. http://dx.doi.org/10.1162/rest.89.3.534

[36] Hemming, R. and Harvey, R. (1983) Occupational Pension Scheme Membership and Retirement Saving. The Economic Journal, 93, 128-144. http://dx.doi.org/10.2307/2232169

[37] Hubbard, G.R. and Skinner, J. (1996) Assessing the Effectiveness of Saving Incentives. Journal of Economic Perspectives, 10, 73-90. http://dx.doi.org/10.1257/jep.10.4.73

[38] Maynard, A. and Qiu, J. (2009) Public Insurance and Private Savings: Who Is Affected and by How Much? Journal of Applied Econometrics, 24, 282-308.

[39] Carrin, G. (2002) Social Health Insurance in Developing Countries: A Continuing Challenge. International Social Security Reviews, 55, 57-69.

[40] Fafchamps, M. and Lund, S. (2003) Risk-Sharing Network in Rural Philippines. Journal of Development Economics, 71, 261-287. http://dx.doi.org/10.1016/S0304-3878(03)00029-4

[41] Hubbard, G.R., Skinner, J. and Zeldes, S.F. (1995) Precautionary Saving and Social Insurance. Journal of Political Economy, 103, 360-399. http://dx.doi.org/10.1086/261987

[42] VARHS06 (2006, 2008) Vietnam Access to Resources Household Survey: Characteristics of the Vietnamese Rural Economy. Central Institute for Economic Management, Hanoi.

[43] Cameron, A.C. and Trivedi, P.K. (2010) Microeconometrics Using Stata. Stata Corp LP, Texas.

[44] Kedir, A.M. and Ibrahim, G. (2011) ROSCAs in Urban Ethiopia: Are the Characteristics of the Institutions More Important than Those of Members? Journal of Development Studies, 47, 998-1016. http://dx.doi.org/10.1080/00220388.2010.536219

[45] Jappelli, T. (1999) The Wealth-Age Profile and the Life-Cycle Hypothesis: A Cohort Analysis with a Time Series of Cross-Section of Italian Households. Review of Income and Wealth, 45, 57-75. http://dx.doi.org/10.1111/j.1475-4991.1999.tb00312.x

[46] Masson, A. (1986) A Cohort Analysis of Wealth Age Profiles Generated by a Simulation Model in France (1949-75). Economic Journal, 96, 173-190. http://dx.doi.org/10.2307/2233432

[47] Mirer, T.W. (1979) The Wealth-Age Relation among the Aged. American Economic Review, 69, 435-443.

[48] Shorrocks, A.F. (1975) The Age-Wealth Relationship: A Cross-Section and Cohort Analysis. The Review of Economics and Statistics, 57, 155-163. http://dx.doi.org/10.2307/1923996

[49] UNFPA (2011) Vietnamese Ethnicity: Analysis of Main Characteristics of General Population and Housing Survey 2009. The UN Population Fund, New York.

[50] Arun, T., Bendig, M. and Arun, S. (2012) Bequest Motives and Determinants of Micro Life Insurance in Sri Lanka. World Development, 40, 1700-1711. http://dx.doi.org/10.1016/j.worlddev.2012.04.010

[51] Chou, S.Y., Liu, J.T. and Huang, C.J. (2004) Health Insurance and Savings over the Life Cycle-A Semiparametric Smooth Coefficient Estimation. Journal of Applied Econometrics, 19, 295-322. http://dx.doi.org/10.1002/jae.735

[52] Chou, S.Y., Liu, J.T. and Hammitt, J.K. (2006) Households' Precautionary Behaviors-The Effect of the Introduction of National Health Insurance in Taiwan. Review of Economics of the Households, 4, 395-421. http://dx.doi.org/10.1007/s11150-006-0014-3

[53] Gruber, J. and Yelowitz, A. (1999) Public Health Insurance and Private Savings. Journal of Political Economy, 107, 1249-1274. http://dx.doi.org/10.1086/250096

[54] Barnett, S. and Brooks, R. (2010) China: Does Government Health and Education Spending Boost Consumption? IMF Working Papers, WP/10/16, Washington DC. 


\section{Appendix}

\section{Appendix 1. Variable definitions.}

\begin{tabular}{|c|c|}
\hline Variables & Description \\
\hline Total flow ratio & Ratio of total flow liquid and productive assets to household net income \\
\hline Flow liquid asset ratio & Ratio of flow liquid assets to household net income \\
\hline Flow productive asset ratio & Ratio of flow productive assets to household net income \\
\hline Total stock ratio & Ratio of total liquid assets and productive assets to household net income \\
\hline Stock liquid asset ratio & Ratio of liquid assets to household net income \\
\hline Stock productive asset ratio & Ratio of productive assets to household net income \\
\hline \multicolumn{2}{|l|}{ Household head characteristics } \\
\hline Gender & Household whose head is male (yes $=1$ ) \\
\hline Edu2 & Household whose head has vocational training, or professional high school or junior diploma (yes $=1$ ) \\
\hline Edu3 & Household whose head has tertiary education (yes $=1$ ) \\
\hline \multicolumn{2}{|l|}{ Household characteristics } \\
\hline LnWealth & Total value of all household assets, natural logarithm \\
\hline Person & Number of family members \\
\hline Young rate & Ratio of number of young people (under 15) to total number of household members (\%) \\
\hline Old rate & Ratio of number of old people (over 60) to total number of household members (\%) \\
\hline \multicolumn{2}{|l|}{ Social network } \\
\hline Supporter & Number of supporters (friends/relatives) outside the family \\
\hline Organization & Household with at least one member in political/social or economic organizations (yes = 1) \\
\hline Assistance & $\begin{array}{l}\text { Number of non-demanded visits from agricultural consultants (extension workers) during } \\
\text { previous } 12 \text { months }\end{array}$ \\
\hline Insurance & Household with at least one member engaging in one type of insurance (yes $=1$ ) \\
\hline \multicolumn{2}{|l|}{ Instruments } \\
\hline Distance & Distance from household to all-weather road \\
\hline Ethnicity & Households in Kinhethnic group (yes $=1$ ) \\
\hline Lnage & Age of household head, natural logarithm \\
\hline Lnage2 & Squares of Lnage \\
\hline Area1 & Household in Northern midlands-mountain areas and former Ha Tay province ${ }^{*}($ yes $=1$ ) \\
\hline Area2 & Household in North Central area(yes $=1$ ) \\
\hline Area3 & Household in Central Highland (yes = 1) \\
\hline Shock & Household facing at least one shock (yes $=1$ ) \\
\hline Household member shocks & $\begin{array}{l}\text { Household facing shocks relating to household members (divorce, abandonment, family disputes, } \\
\text { illness) }\end{array}$ \\
\hline Economic/natural shocks & $\begin{array}{l}\text { Household facing economic and natural shocks (crop prices, unemployment, unsuccessful investment, } \\
\text { loss of land, robbery, theft, floods, landslides, typhoons, storms) }\end{array}$ \\
\hline
\end{tabular}

Note: Household net income is measured within previous 12 months, ${ }^{*}$ Today Ha Tay province is part of Hanoi city. 
Appendix 2a. First-stage IV estimations for all households.

\begin{tabular}{|c|c|c|c|c|c|c|c|c|}
\hline Variables & LnWealth & LnWealth & Supporter & Supporter & Organization & Organization & Insurance & Insuranc \\
\hline Constant & $\begin{array}{c}3.02 \\
(2.74)\end{array}$ & $\begin{array}{c}3.24 \\
(2.77)\end{array}$ & $\begin{array}{c}-7.07^{* * *} \\
(2.27)\end{array}$ & $\begin{array}{l}-2.88 \\
(2.24)\end{array}$ & $\begin{array}{l}-1.52 \\
(1.19)\end{array}$ & $\begin{array}{l}-0.81 \\
(1.19)\end{array}$ & $\begin{array}{l}3.92^{* * *} \\
(0.85)\end{array}$ & $\begin{array}{l}3.01^{* * *} \\
(0.84)\end{array}$ \\
\hline \multicolumn{9}{|c|}{ Household head's characteristics } \\
\hline Gender & $\begin{array}{l}0.27^{* * *} \\
(0.05)\end{array}$ & $\begin{array}{l}0.27^{* * *} \\
(0.05)\end{array}$ & $\begin{array}{l}-0.09^{*} \\
(0.05)\end{array}$ & $\begin{array}{l}-0.04 \\
(0.04)\end{array}$ & $\begin{array}{l}0.05^{* *} \\
(0.02)\end{array}$ & $\begin{array}{l}0.05^{* * *} \\
(0.02)\end{array}$ & $\begin{array}{l}0.004 \\
(0.02)\end{array}$ & $\begin{array}{l}-0.01 \\
(0.02)\end{array}$ \\
\hline Edu2 & $\begin{array}{c}0.12 \\
(0.07)\end{array}$ & $\begin{array}{c}0.11 \\
(0.07)\end{array}$ & $\begin{array}{l}0.14^{* *} \\
(0.06)\end{array}$ & $\begin{array}{c}0.03 \\
(0.06)\end{array}$ & $\begin{array}{l}0.06^{* *} \\
(0.02)\end{array}$ & $\begin{array}{c}0.04 \\
(0.02)\end{array}$ & $\begin{array}{l}0.06^{* *} \\
(0.02)\end{array}$ & $\begin{array}{l}0.08^{* * *} \\
(0.02)\end{array}$ \\
\hline Edu3 & $\begin{array}{c}0.25 \\
(0.16)\end{array}$ & $\begin{array}{c}0.24 \\
(0.16)\end{array}$ & $\begin{array}{c}0.16 \\
(0.15)\end{array}$ & $\begin{array}{c}0.05 \\
(0.15)\end{array}$ & $\begin{array}{l}0.16^{* * *} \\
(0.03)\end{array}$ & $\begin{array}{l}0.14^{* * *} \\
(0.03)\end{array}$ & $\begin{array}{l}0.19^{* * *} \\
(0.02)\end{array}$ & $\begin{array}{l}0.21^{*} \\
(0.02\end{array}$ \\
\hline
\end{tabular}

Household's characteristics

\begin{tabular}{|c|c|c|c|c|c|c|c|c|}
\hline Person & $\begin{array}{l}0.09^{* * *} \\
(0.01)\end{array}$ & $\begin{array}{l}0.10^{* * *} \\
(0.01)\end{array}$ & $\begin{array}{c}-0.04^{* * *} \\
(0.01)\end{array}$ & $\begin{array}{c}-0.001 \\
(0.01)\end{array}$ & $\begin{array}{c}-0.0004 \\
(0.004)\end{array}$ & $\begin{array}{c}0.01 \\
(0.004)\end{array}$ & $\begin{array}{l}0.03^{* * *} \\
(0.003)\end{array}$ & $\begin{array}{l}0.02^{* * *} \\
(0.003)\end{array}$ \\
\hline Young rate & $\begin{array}{c}-0.47^{* * *} \\
(0.10)\end{array}$ & $\begin{array}{c}-0.46^{* * *} \\
(0.10)\end{array}$ & $\begin{array}{l}-0.14 \\
(0.09)\end{array}$ & $\begin{array}{l}-0.05 \\
(0.09)\end{array}$ & $\begin{array}{c}-0.19^{* * *} \\
(0.04)\end{array}$ & $\begin{array}{c}-0.17^{* * *} \\
(0.04)\end{array}$ & $\begin{array}{l}0.09^{* *} \\
(0.04)\end{array}$ & $\begin{array}{l}0.07^{* *} \\
(0.04)\end{array}$ \\
\hline Old rate & $\begin{array}{c}-0.41^{* * *} \\
(0.11)\end{array}$ & $\begin{array}{c}-0.41^{* * *} \\
(0.11)\end{array}$ & $\begin{array}{l}-0.10 \\
(0.10)\end{array}$ & $\begin{array}{l}-0.05 \\
(0.10)\end{array}$ & $\begin{array}{l}-0.01 \\
(0.04)\end{array}$ & $\begin{array}{c}-0.004 \\
(0.04)\end{array}$ & $\begin{array}{l}-0.08^{*} \\
(0.05)\end{array}$ & $\begin{array}{c}-0.09^{* *} \\
(0.04)\end{array}$ \\
\hline Assistance & $\begin{array}{l}0.0006 \\
(0.003)\end{array}$ & $\begin{array}{l}0.0004 \\
(0.003)\end{array}$ & $\begin{array}{l}0.03^{* * *} \\
(0.003)\end{array}$ & $\begin{array}{l}0.02^{* * *} \\
(0.003)\end{array}$ & $\begin{array}{l}0.01^{* * *} \\
(0.001)\end{array}$ & $\begin{array}{l}0.005^{* * * *} \\
(0.001)\end{array}$ & $\begin{array}{c}-0.01^{* * *} \\
(0.001)\end{array}$ & $\begin{array}{c}-0.004^{* * *} \\
(0.001)\end{array}$ \\
\hline
\end{tabular}

Instruments

\begin{tabular}{|c|c|c|c|c|c|c|c|c|}
\hline Distance & $\begin{array}{c}8 \mathrm{e}-05^{* * *} \\
(\mathrm{e}-05)\end{array}$ & $\begin{array}{c}9 \mathrm{e}-05^{* * *} \\
(\mathrm{e}-05)\end{array}$ & $\begin{array}{c}-0.0001^{* * *} \\
\left(3 e^{*}-5\right)\end{array}$ & $\begin{array}{l}-3 \mathrm{e}-05 \\
(2 \mathrm{e}-05)\end{array}$ & $\begin{array}{c}\mathrm{e}-05^{*} \\
(6 \mathrm{e}-06)\end{array}$ & $\begin{array}{l}2 e^{-}-05^{* * *} \\
\left(5 e^{-06}\right)\end{array}$ & $\begin{array}{c}4 \mathrm{e}^{-}-05^{* * *} \\
\left(4 \mathrm{e}^{-06}\right)\end{array}$ & $\begin{array}{l}3 \mathrm{e}-05^{* * *} \\
(3 \mathrm{e}-06)\end{array}$ \\
\hline Lnage & $\begin{array}{l}4.46^{* * *} \\
(1.45)\end{array}$ & $\begin{array}{l}4.33^{* * *} \\
(1.47)\end{array}$ & $\begin{array}{l}4.60^{* * *} \\
(1.21)\end{array}$ & $\begin{array}{l}2.19^{*} \\
(1.19)\end{array}$ & $\begin{array}{c}0.95 \\
(0.62)\end{array}$ & $\begin{array}{c}0.54 \\
(0.62)\end{array}$ & $\begin{array}{c}-1.63^{* * *} \\
(0.46)\end{array}$ & $\begin{array}{c}-1.10^{* *} \\
(0.45)\end{array}$ \\
\hline Lnage2 & $\begin{array}{c}-0.54^{* * *} \\
(0.19)\end{array}$ & $\begin{array}{c}-0.53^{* * *} \\
(0.19)\end{array}$ & $\begin{array}{c}-0.58^{* * *} \\
(0.16)\end{array}$ & $\begin{array}{l}-0.29^{*} \\
(0.16)\end{array}$ & $\begin{array}{l}-0.11 \\
(0.08)\end{array}$ & $\begin{array}{l}-0.06 \\
(0.08)\end{array}$ & $\begin{array}{l}0.20^{* * *} \\
(0.06)\end{array}$ & $\begin{array}{l}0.14^{* *} \\
(0.06)\end{array}$ \\
\hline Area1 & $\begin{array}{c}-0.28^{* * *} \\
(0.08)\end{array}$ & $\begin{array}{c}-0.26^{* * *} \\
(0.08)\end{array}$ & $\begin{array}{c}-0.38^{* * * *} \\
(0.06)\end{array}$ & $\begin{array}{l}-0.12^{*} \\
(0.06)\end{array}$ & $\begin{array}{l}0.28^{* * *} \\
(0.03)\end{array}$ & $\begin{array}{l}0.32^{* * *} \\
(0.03)\end{array}$ & $\begin{array}{c}0.02 \\
(0.03)\end{array}$ & $\begin{array}{l}-0.04 \\
(0.03)\end{array}$ \\
\hline Area2 & $\begin{array}{c}-0.61^{* * *} \\
(0.08)\end{array}$ & $\begin{array}{c}-0.61^{* * *} \\
(0.08)\end{array}$ & $\begin{array}{l}0.40^{* * *} \\
(0.07)\end{array}$ & $\begin{array}{l}0.44^{* * *} \\
(0.07)\end{array}$ & $\begin{array}{l}0.45^{* * *} \\
(0.03)\end{array}$ & $\begin{array}{l}0.45^{* * *} \\
(0.03)\end{array}$ & $\begin{array}{l}0.11^{* * *} \\
(0.03)\end{array}$ & $\begin{array}{l}0.10^{* * *} \\
(0.03)\end{array}$ \\
\hline Area3 & $\begin{array}{c}-0.41^{* * *} \\
(0.09)\end{array}$ & $\begin{array}{c}-0.41^{* * *} \\
(0.09)\end{array}$ & $\begin{array}{c}-0.42^{* * *} \\
(0.06)\end{array}$ & $\begin{array}{c}-0.25^{* * *} \\
(0.06)\end{array}$ & $\begin{array}{l}0.34^{* * * *} \\
(0.03)\end{array}$ & $\begin{array}{l}0.37^{* * *} \\
(0.03)\end{array}$ & $\begin{array}{c}-0.09^{* * *} \\
(0.03)\end{array}$ & $\begin{array}{c}-0.13^{* * *} \\
(0.03)\end{array}$ \\
\hline Ethnicity & & $\begin{array}{c}0.03 \\
(0.04)\end{array}$ & & $\begin{array}{l}0.64^{* * *} \\
(0.04)\end{array}$ & & $\begin{array}{l}0.11^{* * *} \\
(0.02)\end{array}$ & & $\begin{array}{c}-0.14^{* * * *} \\
(0.02)\end{array}$ \\
\hline Observations & 3227 & 3227 & 3227 & 3227 & 3227 & 3227 & 3227 & 3227 \\
\hline R-squared & 0.12 & 0.12 & 0.15 & 0.22 & 0.10 & 0.11 & 0.08 & 0.11 \\
\hline
\end{tabular}

Robust standard errors in parentheses, ${ }^{* * *} \mathrm{p}<0.01,{ }^{* *} \mathrm{p}<0.05,{ }^{*} \mathrm{p}<0.1$. 
Appendix 2b. First-stage IV estimations for "ex ante” households.

\begin{tabular}{|c|c|c|c|c|c|c|c|c|}
\hline Variables & LnWealth & LnWealth & Supporter & Supporter & Organization & Organization & Insurance & Insuranc \\
\hline Constant & $\begin{array}{l}-4.79 \\
(4.34)\end{array}$ & $\begin{array}{l}-4.57 \\
(4.43)\end{array}$ & $\begin{array}{c}-10.38^{* * *} \\
(3.69)\end{array}$ & $\begin{array}{l}-5.32 \\
(3.70)\end{array}$ & $\begin{array}{c}0.46 \\
(1.81)\end{array}$ & $\begin{array}{c}2.14 \\
(1.80)\end{array}$ & $\begin{array}{l}4.76^{* * *} \\
(1.56)\end{array}$ & $\begin{array}{l}3.92^{* *} \\
(1.58)\end{array}$ \\
\hline \multicolumn{9}{|c|}{ Household head's characteristics } \\
\hline Gender & $\begin{array}{l}0.33^{* * * *} \\
(0.09)\end{array}$ & $\begin{array}{l}0.33^{* * *} \\
(0.09)\end{array}$ & $\begin{array}{c}0.05 \\
(0.07)\end{array}$ & $\begin{array}{c}0.07 \\
(0.07)\end{array}$ & $\begin{array}{l}0.05^{*} \\
(0.03)\end{array}$ & $\begin{array}{l}0.06^{*} \\
(0.03)\end{array}$ & $\begin{array}{l}-0.01 \\
(0.03)\end{array}$ & $\begin{array}{l}-0.01 \\
(0.03)\end{array}$ \\
\hline Edu2 & $\begin{array}{l}0.28^{* *} \\
(0.11)\end{array}$ & $\begin{array}{l}0.27^{* *} \\
(0.11)\end{array}$ & $\begin{array}{l}0.19^{* *} \\
(0.09)\end{array}$ & $\begin{array}{c}0.08 \\
(0.09)\end{array}$ & $\begin{array}{c}0.05 \\
(0.04)\end{array}$ & $\begin{array}{c}0.02 \\
(0.04)\end{array}$ & $\begin{array}{l}0.07^{* *} \\
(0.04)\end{array}$ & $\begin{array}{l}0.09^{* *} \\
(0.04)\end{array}$ \\
\hline Edu3 & $\begin{array}{c}0.11 \\
(0.23)\end{array}$ & $\begin{array}{c}0.10 \\
(0.23)\end{array}$ & $\begin{array}{c}0.06 \\
(0.19)\end{array}$ & $\begin{array}{l}-0.04 \\
(0.19)\end{array}$ & $\begin{array}{l}0.20^{* * *} \\
(0.04)\end{array}$ & $\begin{array}{l}0.16^{* * *} \\
(0.04)\end{array}$ & $\begin{array}{l}0.23^{* * *} \\
(0.03)\end{array}$ & $\begin{array}{l}0.25^{* * *} \\
(0.04)\end{array}$ \\
\hline
\end{tabular}

Household's characteristics

$\begin{array}{lcccccccc}\text { Person } & 0.09^{* * *} & 0.09^{* * *} & -0.04^{* *} & 0.00 & 0.01 & 0.02^{* * *} & 0.04^{* * *} & 0.04^{* * * *} \\ & (0.02) & (0.02) & (0.02) & (0.02) & (0.01) & (0.01) & (0.01) & (0.01) \\ \text { Young rate } & -0.25 & -0.25 & -0.08 & -0.04 & -0.17^{* *} & -0.15^{* *} & 0.06 & 0.05 \\ & (0.18) & (0.18) & (0.15) & (0.15) & (0.07) & (0.07) & (0.06) & (0.06) \\ & & & & & & & & \\ \text { Old rate } & -0.42^{* *} & -0.42^{* *} & -0.08 & -0.04 & 0.01 & 0.03 & -0.08 & -0.09 \\ & (0.17) & (0.17) & (0.15) & (0.15) & (0.07) & (0.06) & (0.07) & (0.07) \\ & & & & & & & & \\ \text { Assistance } & 0.01 & 0.01 & 0.02^{* * *} & 0.01^{* * *} & 0.002 & 0.001 & -0.01^{* * *} & -0.01^{* * *} \\ & (0.01) & (0.01) & (0.004) & (0.004) & (0.002) & (0.002) & (0.002) & (0.002)\end{array}$

Instruments

\begin{tabular}{|c|c|c|c|c|c|c|c|c|}
\hline Distance & $\begin{array}{c}0.0001^{* * *} \\
\left(2 e^{-05}\right)\end{array}$ & $\begin{array}{c}0.0001^{* * *} \\
\left(2 e^{-05}\right)\end{array}$ & $\begin{array}{c}-8 \mathrm{e}-05^{* * *} \\
(2 \mathrm{e}-05)\end{array}$ & $\begin{array}{c}-9 \mathrm{e}-06 \\
(\mathrm{e}-05)\end{array}$ & $\begin{array}{c}\mathrm{e}-05 \\
(\mathrm{e}-05)\end{array}$ & $\begin{array}{c}4 e^{-}-05^{* * *} \\
(7 e-06)\end{array}$ & $\begin{array}{l}4 e^{-}-05^{* * *} \\
(8 \mathrm{e}-07)\end{array}$ & $\begin{array}{l}3 e-05^{* * *} \\
(7 e-06)\end{array}$ \\
\hline Lnage & $\begin{array}{l}8.30^{* * *} \\
(2.30)\end{array}$ & $\begin{array}{l}8.18^{* * * *} \\
(2.35)\end{array}$ & $\begin{array}{l}6.14^{* * *} \\
(1.96)\end{array}$ & $\begin{array}{c}3.31^{*} \\
(1.96)\end{array}$ & $\begin{array}{l}-0.05 \\
(0.94)\end{array}$ & $\begin{array}{l}-0.99 \\
(0.94)\end{array}$ & $\begin{array}{c}-2.03^{* *} \\
(0.82)\end{array}$ & $\begin{array}{l}-1.56^{*} \\
(0.83)\end{array}$ \\
\hline Lnage2 & $\begin{array}{c}-1.02^{* * *} \\
(0.30)\end{array}$ & $\begin{array}{c}-1.00^{* * *} \\
(0.31)\end{array}$ & $\begin{array}{c}-0.76^{* * *} \\
(0.26)\end{array}$ & $\begin{array}{l}-0.42 \\
(0.26)\end{array}$ & $\begin{array}{c}0.01 \\
(0.12)\end{array}$ & $\begin{array}{c}0.13 \\
(0.12)\end{array}$ & $\begin{array}{l}0.25^{* *} \\
(0.11)\end{array}$ & $\begin{array}{l}0.20^{*} \\
(0.11)\end{array}$ \\
\hline Area1 & $\begin{array}{c}-0.26^{* * *} \\
(0.10)\end{array}$ & $\begin{array}{l}-0.25^{* *} \\
(0.10)\end{array}$ & $\begin{array}{c}-0.34^{* * *} \\
(0.09)\end{array}$ & $\begin{array}{l}-0.16^{*} \\
(0.09)\end{array}$ & $\begin{array}{l}0.22^{* * *} \\
(0.04)\end{array}$ & $\begin{array}{l}0.28^{* * *} \\
(0.04)\end{array}$ & $\begin{array}{c}-0.09^{* * *} \\
(0.03)\end{array}$ & $\begin{array}{c}-0.12^{* * *} \\
(0.04)\end{array}$ \\
\hline Area2 & $\begin{array}{c}-0.65^{* * *} \\
(0.11)\end{array}$ & $\begin{array}{c}-0.65^{* * *} \\
(0.11)\end{array}$ & $\begin{array}{l}0.32^{* * *} \\
(0.09)\end{array}$ & $\begin{array}{l}0.36^{* * *} \\
(0.09)\end{array}$ & $\begin{array}{l}0.41^{* * *} \\
(0.04)\end{array}$ & $\begin{array}{l}0.42^{* * *} \\
(0.04)\end{array}$ & $\begin{array}{c}0.06 \\
(0.04)\end{array}$ & $\begin{array}{c}0.05 \\
(0.04)\end{array}$ \\
\hline Area3 & $\begin{array}{c}-0.47^{* * *} \\
(0.12)\end{array}$ & $\begin{array}{c}-0.46^{* * *} \\
(0.12)\end{array}$ & $\begin{array}{c}-0.41^{* * *} \\
(0.08)\end{array}$ & $\begin{array}{c}-0.26^{* * *} \\
(0.09)\end{array}$ & $\begin{array}{l}0.26^{* * *} \\
(0.04)\end{array}$ & $\begin{array}{l}0.31^{* * *} \\
(0.04)\end{array}$ & $\begin{array}{c}-0.19^{* * *} \\
(0.04)\end{array}$ & $\begin{array}{c}-0.22^{* * *} \\
(0.04)\end{array}$ \\
\hline Ethnicity & & $\begin{array}{c}0.03 \\
(0.07)\end{array}$ & & $\begin{array}{l}0.59^{* * *} \\
(0.06)\end{array}$ & & $\begin{array}{l}0.20^{* * *} \\
(0.03)\end{array}$ & & $\begin{array}{c}-0.10^{* * *} \\
(0.03)\end{array}$ \\
\hline Observations & 1352 & 1352 & 1352 & 1352 & 1352 & 1352 & 1352 & 1352 \\
\hline R-squared & 0.13 & 0.13 & 0.12 & 0.17 & 0.08 & 0.11 & 0.11 & 0.12 \\
\hline
\end{tabular}

Robust standard errors in parentheses, ${ }^{* * *} \mathrm{p}<0.01,{ }^{* *} \mathrm{p}<0.05,{ }^{*} \mathrm{p}<0.1$. 
Appendix 2c. First-stage IV estimations for “ex post” households.

\begin{tabular}{|c|c|c|c|c|c|c|c|c|}
\hline Variables & LnWealth & LnWealth & Supporter & Supporter & Organization & Organization & Insurance & Insuranc \\
\hline Constant & $\begin{array}{l}8.02^{* *} \\
(3.40)\end{array}$ & $\begin{array}{l}8.19^{* *} \\
(3.42)\end{array}$ & $\begin{array}{l}-4.75^{*} \\
(2.87)\end{array}$ & $\begin{array}{l}-1.32 \\
(2.79)\end{array}$ & $\begin{array}{l}-2.61^{*} \\
(1.56)\end{array}$ & $\begin{array}{l}-2.32 \\
(1.56)\end{array}$ & $\begin{array}{l}3.42^{* * *} \\
(0.95)\end{array}$ & $\begin{array}{c}2.60^{* * *} \\
(0.92)\end{array}$ \\
\hline \multicolumn{9}{|c|}{ Household head's characteristics } \\
\hline Gender & $\begin{array}{l}0.21^{* * *} \\
(0.07)\end{array}$ & $\begin{array}{l}0.22^{* * *} \\
(0.07)\end{array}$ & $\begin{array}{c}-0.19^{* * *} \\
(0.06)\end{array}$ & $\begin{array}{l}-0.12^{* *} \\
(0.06)\end{array}$ & $\begin{array}{c}0.04 \\
(0.02)\end{array}$ & $\begin{array}{c}0.04^{*} \\
(0.02)\end{array}$ & $\begin{array}{c}0.01 \\
(0.03)\end{array}$ & $\begin{array}{c}-0.004 \\
(0.03)\end{array}$ \\
\hline Edu2 & $\begin{array}{l}-0.05 \\
(0.09)\end{array}$ & $\begin{array}{l}-0.06 \\
(0.09)\end{array}$ & $\begin{array}{c}0.09 \\
(0.10)\end{array}$ & $\begin{array}{c}-0.004 \\
(0.10)\end{array}$ & $\begin{array}{l}0.07^{* *} \\
(0.03)\end{array}$ & $\begin{array}{l}0.06^{* *} \\
(0.03)\end{array}$ & $\begin{array}{c}0.06^{*} \\
(0.03)\end{array}$ & $\begin{array}{l}0.08^{* *} \\
(0.03)\end{array}$ \\
\hline Edu3 & $\begin{array}{l}0.48^{* * *} \\
(0.14)\end{array}$ & $\begin{array}{l}0.47^{* * *} \\
(0.14)\end{array}$ & $\begin{array}{c}0.33 \\
(0.25)\end{array}$ & $\begin{array}{c}0.25 \\
(0.24)\end{array}$ & $\begin{array}{l}0.14^{* * *} \\
(0.06)\end{array}$ & $\begin{array}{l}0.14^{* *} \\
(0.05)\end{array}$ & $\begin{array}{l}0.17^{* * *} \\
(0.02)\end{array}$ & $\begin{array}{l}0.20^{* * *} \\
(0.03)\end{array}$ \\
\hline
\end{tabular}

Household's characteristics

\begin{tabular}{|c|c|c|c|c|c|c|c|c|}
\hline Person & $\begin{array}{l}0.10^{* * *} \\
(0.01)\end{array}$ & $\begin{array}{l}0.10^{* * *} \\
(0.01)\end{array}$ & $\begin{array}{c}-0.05^{* * *} \\
(0.01)\end{array}$ & $\begin{array}{l}-0.01 \\
(0.01)\end{array}$ & $\begin{array}{l}-0.01 \\
(0.01)\end{array}$ & $\begin{array}{c}-0.005 \\
(0.01)\end{array}$ & $\begin{array}{l}0.02^{* * *} \\
(0.004)\end{array}$ & $\begin{array}{l}0.01^{* * *} \\
(0.004)\end{array}$ \\
\hline Young rate & $\begin{array}{c}-0.60^{* * *} \\
(0.12)\end{array}$ & $\begin{array}{c}-0.59^{* * *} \\
(0.12)\end{array}$ & $\begin{array}{l}-0.15 \\
(0.12)\end{array}$ & $\begin{array}{l}-0.03 \\
(0.11)\end{array}$ & $\begin{array}{c}-0.20^{* * *} \\
(0.05)\end{array}$ & $\begin{array}{c}-0.19^{* * *} \\
(0.05)\end{array}$ & $\begin{array}{l}0.12^{* *} \\
(0.05)\end{array}$ & $\begin{array}{l}0.09^{* *} \\
(0.04)\end{array}$ \\
\hline Old rate & $\begin{array}{c}-0.38^{* * *} \\
(0.14)\end{array}$ & $\begin{array}{c}-0.37^{* * *} \\
(0.14)\end{array}$ & $\begin{array}{l}-0.08 \\
(0.14)\end{array}$ & $\begin{array}{l}-0.04 \\
(0.14)\end{array}$ & $\begin{array}{l}0.005 \\
(0.05)\end{array}$ & $\begin{array}{c}0.01 \\
(0.05)\end{array}$ & $\begin{array}{l}-0.06 \\
(0.06)\end{array}$ & $\begin{array}{l}-0.07 \\
(0.06)\end{array}$ \\
\hline Assistance & $\begin{array}{l}-0.003 \\
(0.004)\end{array}$ & $\begin{array}{l}-0.004 \\
(0.004)\end{array}$ & $\begin{array}{l}0.03^{* * *} \\
(0.004)\end{array}$ & $\begin{array}{l}0.02^{* * *} \\
(0.004)\end{array}$ & $\begin{array}{l}0.01^{* * *} \\
(0.001)\end{array}$ & $\begin{array}{l}0.01^{* * *} \\
(0.001)\end{array}$ & $\begin{array}{l}-0.002 \\
(0.001)\end{array}$ & $\begin{array}{l}-0.003 \\
(0.002)\end{array}$ \\
\hline
\end{tabular}

Instruments

\begin{tabular}{|c|c|c|c|c|c|c|c|c|}
\hline Distance & $\begin{array}{l}8 \mathrm{e}-05^{* * *} \\
(2 \mathrm{e}-05)\end{array}$ & $\begin{array}{l}8 \mathrm{e}-05^{* * *} \\
(2 \mathrm{e}-05)\end{array}$ & $\begin{array}{c}-0.0001^{* * *} \\
\left(4 \mathrm{e}^{*}-05\right)\end{array}$ & $\begin{array}{l}-6 \mathrm{e}-05^{* * *} \\
(2 \mathrm{e}-05)\end{array}$ & $\begin{array}{c}5 e^{-}-06 \\
\left(9 e^{-06)}\right.\end{array}$ & $\begin{array}{c}\mathrm{e}-05 \\
(8 \mathrm{e}-06)\end{array}$ & $\begin{array}{c}3 e-05^{* * *} \\
(5 e-06)\end{array}$ & $\begin{array}{l}9 e^{-}-06^{*} \\
\left(5 e^{-06}\right)\end{array}$ \\
\hline Lnage & $\begin{array}{c}1.98 \\
(1.80)\end{array}$ & $\begin{array}{c}1.87 \\
(1.81)\end{array}$ & $\begin{array}{l}3.54^{* *} \\
(1.54)\end{array}$ & $\begin{array}{c}1.50 \\
(1.50)\end{array}$ & $\begin{array}{l}1.50^{*} \\
(0.82)\end{array}$ & $\begin{array}{c}1.33 \\
(0.82)\end{array}$ & $\begin{array}{c}-1.39^{* * *} \\
(0.52)\end{array}$ & $\begin{array}{c}-0.90^{*} \\
(0.50)\end{array}$ \\
\hline Lnage2 & $\begin{array}{l}-0.23 \\
(0.24)\end{array}$ & $\begin{array}{l}-0.22 \\
(0.24)\end{array}$ & $\begin{array}{c}-0.45^{* *} \\
(0.21)\end{array}$ & $\begin{array}{l}-0.21 \\
(0.20)\end{array}$ & $\begin{array}{l}-0.18^{*} \\
(0.11)\end{array}$ & $\begin{array}{l}-0.16 \\
(0.11)\end{array}$ & $\begin{array}{l}0.17^{* *} \\
(0.07)\end{array}$ & $\begin{array}{c}0.11^{*} \\
(0.07)\end{array}$ \\
\hline Area1 & $\begin{array}{l}-0.27^{* *} \\
(0.12)\end{array}$ & $\begin{array}{l}-0.25^{* *} \\
(0.12)\end{array}$ & $\begin{array}{c}-0.44^{* * *} \\
(0.09)\end{array}$ & $\begin{array}{l}-0.12 \\
(0.10)\end{array}$ & $\begin{array}{l}0.32^{* * * *} \\
(0.05)\end{array}$ & $\begin{array}{l}0.35^{* * *} \\
(0.05)\end{array}$ & $\begin{array}{l}0.11^{* *} \\
(0.04)\end{array}$ & $\begin{array}{c}0.03 \\
(0.05)\end{array}$ \\
\hline Area2 & $\begin{array}{c}-0.59^{* * *} \\
(0.12)\end{array}$ & $\begin{array}{c}-0.59^{* * *} \\
(0.12)\end{array}$ & $\begin{array}{l}0.43^{* * *} \\
(0.10)\end{array}$ & $\begin{array}{l}0.46^{* * *} \\
(0.10)\end{array}$ & $\begin{array}{l}0.48^{* * *} \\
(0.05)\end{array}$ & $\begin{array}{l}0.48^{* * *} \\
(0.05)\end{array}$ & $\begin{array}{l}0.17^{* * *} \\
(0.05)\end{array}$ & $\begin{array}{l}0.16^{* * *} \\
(0.05)\end{array}$ \\
\hline Area3 & $\begin{array}{c}-0.34^{* * *} \\
(0.13)\end{array}$ & $\begin{array}{c}-0.33^{* * *} \\
(0.13)\end{array}$ & $\begin{array}{c}-0.44^{* * *} \\
(0.10)\end{array}$ & $\begin{array}{c}-0.25^{* *} \\
(0.10)\end{array}$ & $\begin{array}{l}0.41^{* * *} \\
(0.05)\end{array}$ & $\begin{array}{l}0.42^{* * *} \\
(0.05)\end{array}$ & $\begin{array}{c}0.02 \\
(0.05)\end{array}$ & $\begin{array}{l}-0.03 \\
(0.05)\end{array}$ \\
\hline Ethnicity & & $\begin{array}{c}0.03 \\
(0.05)\end{array}$ & & $\begin{array}{l}0.68^{* * *} \\
(0.05)\end{array}$ & & $\begin{array}{l}0.06^{* * *} \\
(0.02)\end{array}$ & & $\begin{array}{c}-0.16^{* *+} \\
(0.02)\end{array}$ \\
\hline Observations & 1875 & 1875 & 1875 & 1875 & 1875 & 1875 & 1875 & 1875 \\
\hline R-squared & 0.11 & 0.11 & 0.19 & 0.27 & 0.13 & 0.14 & 0.07 & 0.11 \\
\hline
\end{tabular}

Robust standard errors in parentheses, ${ }^{* * *} \mathrm{p}<0.01,{ }^{* *} \mathrm{p}<0.05,{ }^{*} \mathrm{p}<0.1$. 
Scientific Research Publishing (SCIRP) is one of the largest Open Access journal publishers. It is currently publishing more than 200 open access, online, peer-reviewed journals covering a wide range of academic disciplines. SCIRP serves the worldwide academic communities and contributes to the progress and application of science with its publication.

Other selected journals from SCIRP are listed as below. Submit your manuscript to us via either submit@scirp.org or Online Submission Portal.
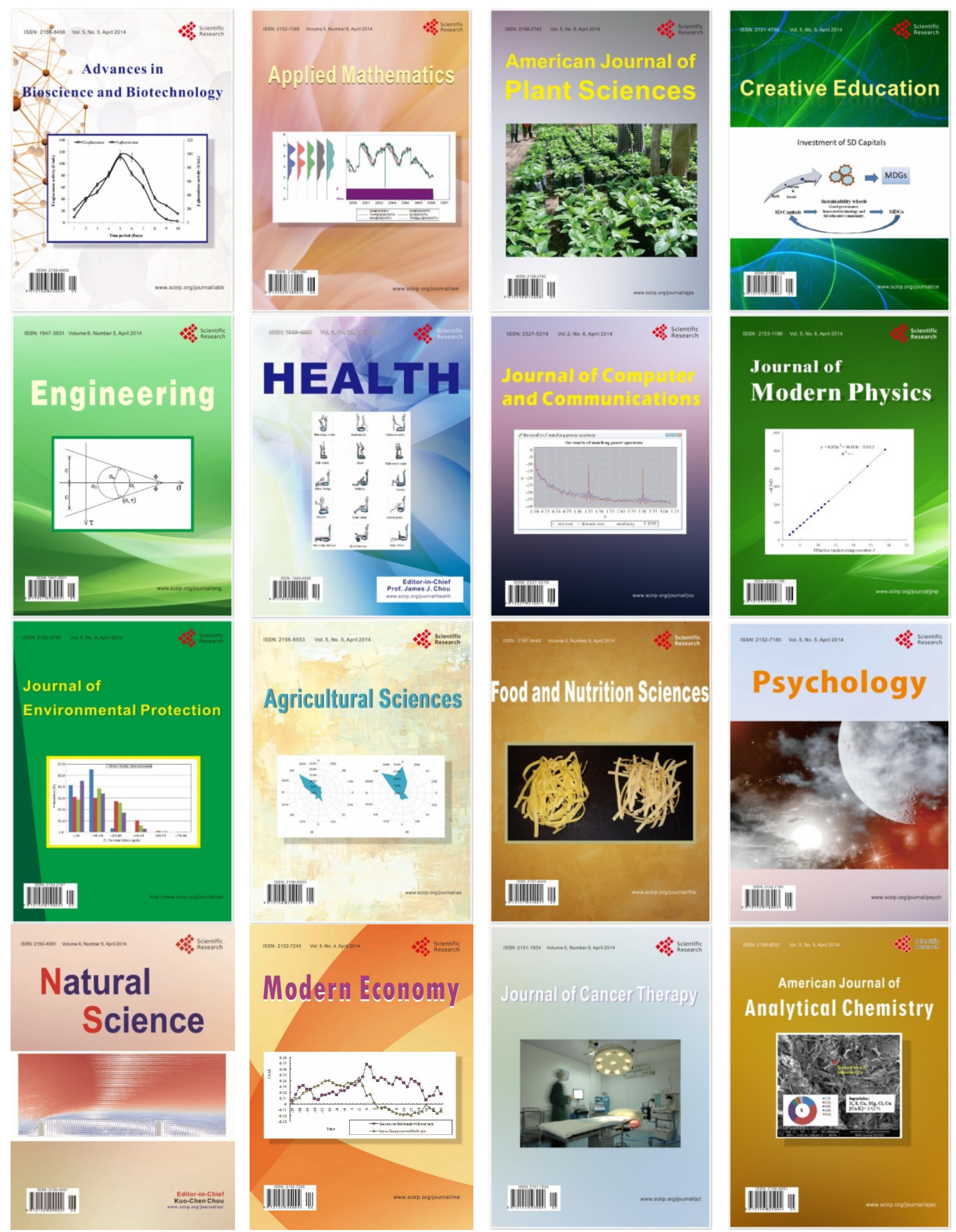